\title{
Host Transcription Factors in Hepatitis B Virus RNA Synthesis
}

\author{
Kristi L. Turton ${ }^{1}{ }^{(}$, Vanessa Meier-Stephenson ${ }^{1,2}{ }^{\oplus}$, Maulik D. Badmalia ${ }^{1}$, Carla S. Coffin ${ }^{2,3}$ and \\ Trushar R. Patel $1,2,4, *$ D \\ 1 Alberta RNA Research and Training Institute, Department of Chemistry and Biochemistry, \\ University of Lethbridge, 4401 University Dr. W., Lethbridge, AB T1K 3M4, Canada; \\ kristi.turton@uleth.ca (K.L.T.); vmeierstephenson@gmail.com (V.M.-S.); maulik.badmalia@uleth.ca (M.D.B.) \\ 2 Department of Microbiology, Immunology and Infectious Diseases, Cumming, School of Medicine, \\ University of Calgary, 2500 University Dr. N.W., Calgary, AB T2N 1N4, Canada; cscoffin@ucalgary.ca \\ 3 Department of Medicine, Division of Gastroenterology and Hepatology, University of Calgary, \\ 140329 St. N.W., Calgary, AB T2N 2T9, Canada \\ 4 Discovery Lab, Faculty of Medicine \& Dentistry, and the Li Ka Shing Institute of Virology, \\ University of Alberta, 6-010 Katz Center for Health Research, Edmonton, AB T6G 2E1, Canada \\ * Correspondence: trushar.patel@uleth.ca
}

Received: 5 December 2019; Accepted: 28 January 2020; Published: 30 January 2020

\begin{abstract}
The hepatitis B virus (HBV) chronically infects over 250 million people worldwide and is one of the leading causes of liver cancer and hepatocellular carcinoma. HBV persistence is due in part to the highly stable HBV minichromosome or HBV covalently closed circular DNA (cccDNA) that resides in the nucleus. As HBV replication requires the help of host transcription factors to replicate, focusing on host protein-HBV genome interactions may reveal insights into new drug targets against cccDNA. The structural details on such complexes, however, remain poorly defined. In this review, the current literature regarding host transcription factors' interactions with HBV cccDNA is discussed.
\end{abstract}

Keywords: hepatitis B virus (HBV); viral replication; transcription factors; covalently closed circular DNA (cccDNA); host-viral interactions

\section{Introduction}

The hepatitis B virus (HBV) is estimated to chronically infect 257 million people worldwide [1]. Chronic HBV infection can promote liver fibrosis and cirrhosis and is also independently associated with hepatocellular carcinoma [2-7]. HBV persists in part due to its resilient minigenome, the covalently closed circular DNA (cccDNA), which resides in the nucleus of the infected cells and acts as the template for all HBV RNA production. The HBV genome can integrate and exist within the host genome $[7,8]$. Current therapies against HBV, including the nucleoside/tide analogues (NAs), are effective at targeting viral reverse transcriptase activity and reducing viral replication but they do not directly target the cccDNA [9,10], often leading to relapse of viremia once therapies are stopped. Eradication of HBV cccDNA is essential to ultimately achieve a virological or sterilizing cure of HBV infection.

HBV belongs to the Hepadnaviridae family and has one of the smallest, compact viral genomes $(\sim 3.2 \mathrm{~kb})$, that encodes five RNA transcripts and seven proteins. Its small size limits the number of viral proteins or nucleic acid sequences available for targeting to inhibit HBV replication. A feature common to all viruses, including HBV, is the requirement of their genome to interact with host proteins to complete the viral replication cycle. Targeting this interaction between the HBV cccDNA and host proteins could represent a potential therapeutic target.

Transcription factors function by interacting with DNA sequences upstream of the gene to be transcribed, i.e., promoter regions, to control transcriptional activity, where regulation can take the 
form of initiation and/or inhibition of transcription [11,12]. The messenger RNA transcripts of the HBV genome (including its pre-genomic RNA [pgRNA] replication intermediate) are under the control of four promoter regions-preS1, preS2, X-promoter, and pre-core/core promoters-and two enhancers, ENI and ENII (Figure 1). Several host transcription factors are recruited to these sites in cccDNA to enable HBV replication $[3,11,13]$. These transcription factors can be classified as those unique to hepatocytes or present in many types of cells, i.e., ubiquitous transcription factors. Understanding the interactions between host transcription factors and the HBV genome will enhance our knowledge of HBV replication.

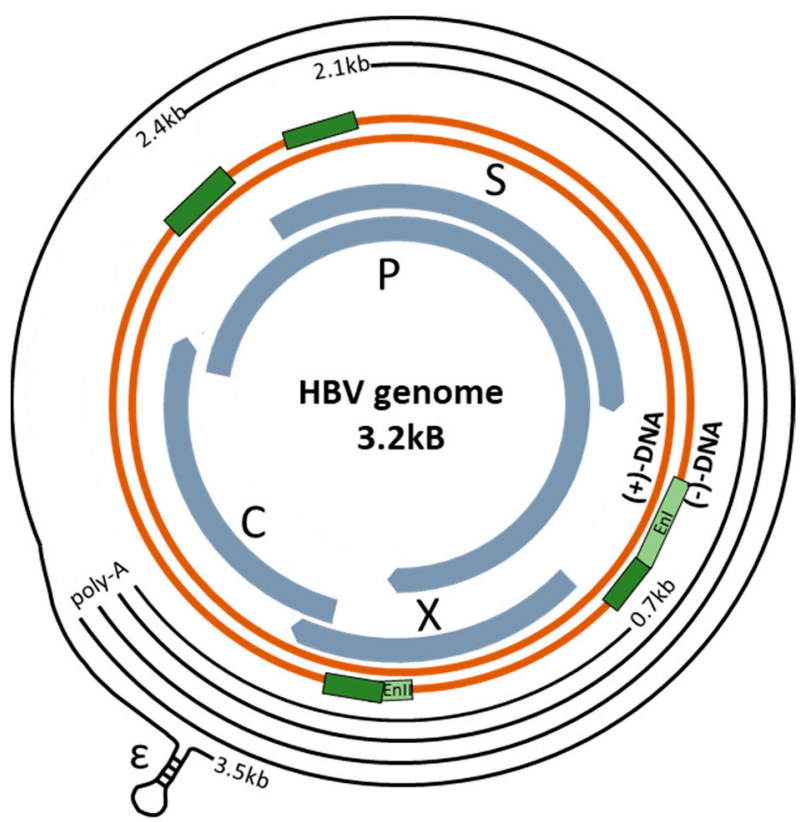

Figure 1. Schematic of the hepatitis B virus (HBV) circular genome (dark orange parallel lines). The outer black lines represent the RNA transcripts produced, all ending in the poly-A tail. The promoter regions are denoted by the dark green rectangles preceding each of these transcripts, and the Enhancer regions I and II, (EnI and EnII) are denoted by the light green rectangles. The thicker inner arrows represent the open reading frames, encoding for the $\mathrm{C}$ (core), $\mathrm{P}$ (polymerase), $\mathrm{S}$ (surface), and $\mathrm{X}$ proteins. The encapsidation signal, $\epsilon$, is also noted.

In this review, we summarize the literature on the various host proteins known to act as transcription factors for HBV replication. We highlight their functions in the host cell, delineate whether selective inhibition is feasible and include structural or sequence-specific information relevant to the interaction with HBV.

\section{The HBV Genome and Control of Viral Replication}

HBV belongs to the Hepadnaviridae family and, as a virion, contains partially double-stranded relaxed circular DNA (rcDNA) (Figure 1). Its virion has one of the smallest genomes at $\sim 3.2 \mathrm{kbp}$ and is contained within the nucleocapsid core that is in turn surrounded by a lipoprotein envelope composed of surface glycoproteins. The primary target of HBV is liver hepatocytes where HBV pre-S1 protein interacts with the sodium taurocholate cotransporting polypeptide (NTCP) and the epidermal growth factor receptor to enter into hepatocytes [14,15]. Once in the host cells, the viral envelope disintegrates and the nucleocapsid localizes into the nucleus with the help of HBV core protein (contains nuclear localization signal) [16]. In the nucleus, the HBV rcDNA undergoes processing to remove the polymerase from the minus strand, remove an RNA oligomer in the positive strand, and synthesize the RNA fragment to a complete positive strand to ultimately form covalently closed circular DNA (cccDNA) [17]. The cccDNA is then bound to histones creating the compact, stable form of the virus 
from which all the viral RNA transcripts are produced, including pgRNA [18,19]. The pgRNA (positive strand) is transcribed from cccDNA and exported from the nucleus to the cytoplasm where viral proteins are synthesized using host cell machinery. It is estimated that median 1.5 copies of cccDNA can be found in each individual hepatocyte [20]. However, the viral and host factors that regulate the formation of cccDNA and control cccDNA copy numbers remain elusive.

The HBV genome is comprised of four overlapping open reading frames (ORFs) that code for the surface $(S)$, core $(C)$, polymerase $(P)$ and X proteins (Figure 1) $[4,5,21]$. The HBV S proteins, comprising of large (L), middle (M), and small $(\mathrm{S})$ proteins make up the envelope of the virion; the preC-C protein that encodes the viral nucleocapsid; and the viral $\mathrm{P}$ or reverse transcriptase, which aids genome synthesis [3,5,22-24]. Additionally, the pre-C protein can undergo C-terminal truncation forming the accessory protein HBV e antigen (HBeAg) [25]. The $X$ protein, also known as HBx, aids viral replication by interacting with and transactivating host factors to prevent an antiviral response or by facilitating proviral cellular activity [26-28]. For example, Decorsière et al. determined that HBx interacts with host proteins in the ubiquitin-proteasome system in order to degrade viral suppressor proteins [29,30]. Additionally, HBx binds to the cccDNA which has been hypothesized to modulate HBV transcription possibly by modifying the epigenetic modifications that occur in vivo [31]. Further, it has been found to play important roles in the epigenetic control of cccDNA processing and stability via the recruitment of histone-modifying enzymes [31]. There are also cis-elements present within the HBV genome known as enhancer elements (EN) and negative regulating elements (NRE), which regulate overall viral promoter activity $[5,17,32]$. The two enhancer regions (ENI and ENII) are of interest due to the high amount of transcription binding activity in this region [32].

This review will summarize the research on HBV transcription factors, broadly classified into ubiquitous and liver-enriched transcription factors. The current understanding of interactions between the cccDNA genome and host transcription factors are discussed in the context of future antiviral strategies to achieve an HBV cure.

\section{Transcription Factors}

Host transcription factors discussed in the current review can be classified as either ubiquitous (generally found in all cell types) and liver-enriched (unique to hepatocytes). As the HBV cccDNA resides in the nucleus of hepatocytes, both categories are candidates for aiding viral transcription, and therefore potential therapeutic targets (Figure 2).

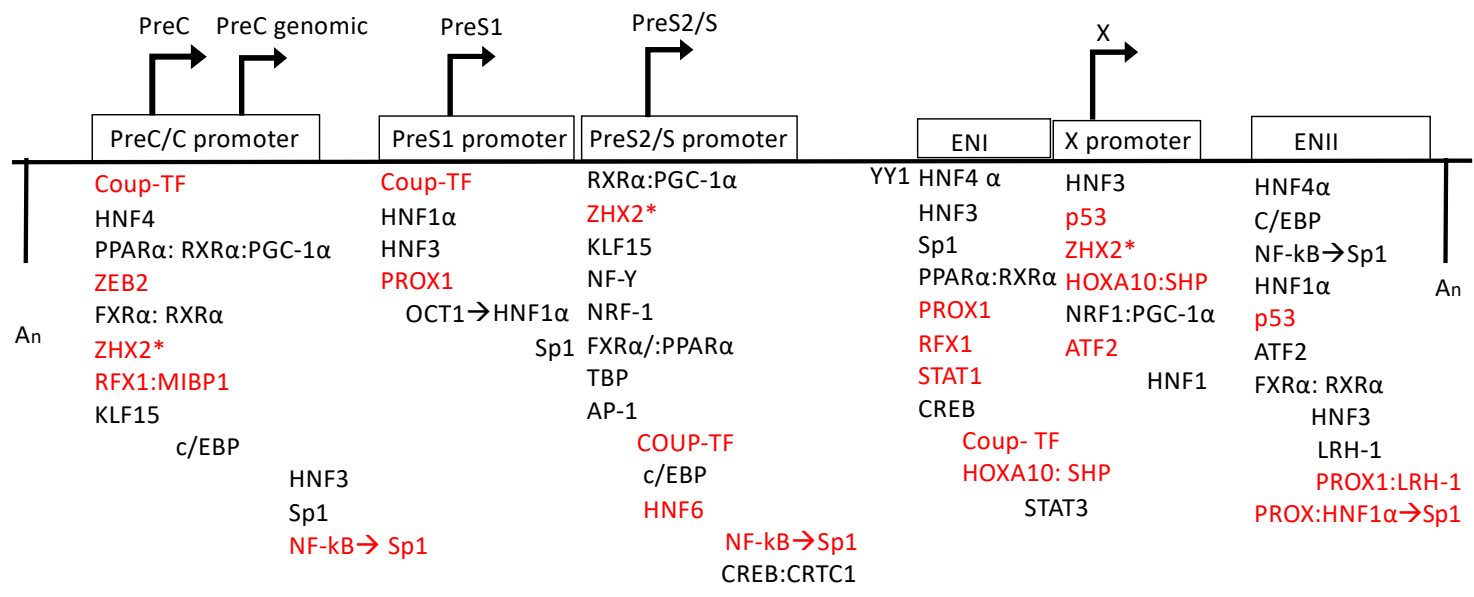

Figure 2. Relative positions of the binding sites of host transcription factors on the HBV genome. Promoter and enhancer sites are represented by the boxes and the directional arrow indicates the transcript produced. The arrows from one transcription factor to another represents an event in which one factor influences the binding activity of another. The two An sites represent the polyadenylation sites in the linearized genome schematic. Transcription factor activity has been indicated in which red 
represents inhibition of HBV transcription and black indicates activation of transcription. The lists of transcription factors are positioned to represent where they bind to the genome where they are generally positioned to $5^{\prime}$ or $3^{\prime}$ of the promoter/enhancer region (not to scale). Asterisks indicate that the specific positioning of the transcription factor is not yet known.

\subsection{Ubiquitous Transcription Factors}

Ubiquitous transcription factors are found in essentially all cell types and are associated with various cellular processes such as cell proliferation, cell differentiation and host immune response. They can give an insight on viral replication in all host cell types, and the clinical/disease consequences of persistent viral infection. The transcription factors discussed in this review are summarized in Table 1.

Table 1. A list of transcription factors and their effect on viral replication.

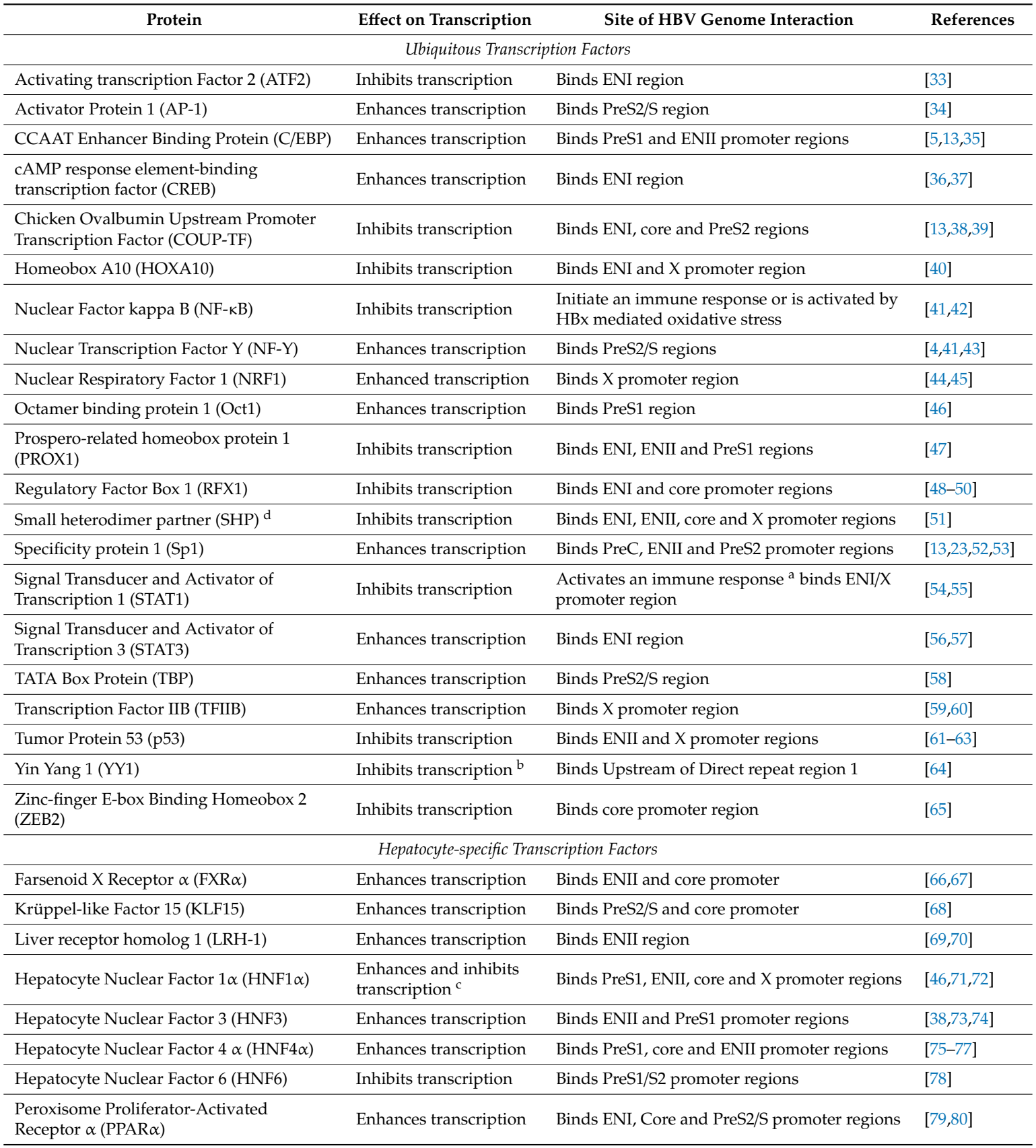


Table 1. Cont

\begin{tabular}{llll}
\hline \multicolumn{1}{c}{ Protein } & Effect on Transcription & \multicolumn{1}{c}{ Site of HBV Genome Interaction } & \multicolumn{1}{c}{ References } \\
\hline Retinoid X Receptor $\alpha(\operatorname{RXR} \alpha)$ & Enhances transcription & Binds ENI, Core and S promoter & [80,81] \\
\hline Zinc Finger and Homeoboxes 2 (ZHX2) & Inhibits transcription & Binds X, core and PreS2 promoter & [82] \\
\hline
\end{tabular}

a Through signal transduction STAT1 can inhibit HBV. However, HBx actively prevents its activation, limiting STAT1's effectiveness against HBV infection. ${ }^{b}$ With YY1's interaction with the direct repeat region HBV replication inhibition occurs. However, other studies indicate its important role in integrating the HBV DNA into the host genome. ${ }^{\mathrm{c}} \mathrm{HNF} 1$, when interacting with NF-kB, can inhibit HBV replication. With the binding of the ENII, PreS1, core and X promoter, there is an enhancement in activity. ${ }^{\mathrm{d}}$ SHP is recruited by other transcription factors to facilitate HBV replication repression.

\subsubsection{Nuclear Transcription Factor $Y$}

Nuclear transcription factor NF-Y is composed of three protein subunits, NF-YA, NF-YB and NF-YC. With the formation of the heterotrimer via histone fold domains in each subunit, NF-Y binds to the CCAAT binding motif of genomic DNA $[83,84]$. It is associated with multiple cellular processes such as cell proliferation, the cell cycle, and responds to cellular events such as DNA damage [85]. NF-Y is also linked with the posttranslational modifications of histone proteins by recruiting enzymes that both methylate and acetylate histone proteins $[84,86]$. In HBV infection, NF-Y has been confirmed to bind to the $\mathrm{S}$ promoter region in the CCAAT binding domain and initiate HBV S protein transcription in both in vitro and in vivo models [4]. A mutant version lacking the binding domain displayed a 10-fold decrease in HBV surface antigen (HBsAg) expression compared to wildtype infection, suggesting that NF-Y is essential for HBV replication [4]. NF-Y also aids shuttling chaperone proteins to the endoplasmic reticulum, possibly triggered by the accumulation of HBV S proteins in an unfolded state, providing additional evidence for the role of this factor in HBV replication [87].

\subsubsection{Nuclear Factor kappa B}

Nuclear Factor kappa B (NF-kB) is a sequence-specific DNA binding protein (GGGRNYYYYC), where $\mathrm{R}$ represents a purine, $\mathrm{Y}$ represents a pyrimidine and $\mathrm{N}$ represents any nucleotide) that can bind to DNA as a homodimer or a heterodimer [88]. NF- $\mathrm{kB}$ is consisting of two subunits p50 and p65, which dimerize via the binding of the Rel homology regions in each subunit and interacts with palindromic sites in the DNA, known as kB sites [89,90].

NF- $\mathrm{kB}$ acts as a regulating element for both innate and adaptive cellular immune responses. It is associated with cellular processes such as angiogenesis, apoptosis, cell proliferation, and migration $[13,88]$. In the host cell, NF- $\mathrm{kB}$ expression is induced by infection with microbial pathogens, oxidative stress or DNA damage [88]. Once activated, it binds to promoters to initiate transcription of immune-associated proteins such as interleukin 6 (IL-6) [91]. Previous studies in Huh7 and HepG2 cell lines have revealed that NF-KB is able to inhibit transcription of the HBV genome $[13,92]$ due to its activation after the induction of oxidative stress by HBx [42]. This activation may be a residual effect as $\mathrm{HBx}$ is proposed to modulate host cell transcription through interactions with Ras and PKC pathways [93]. Although the response from NF- $\mathrm{KB}$ is to prevent $\mathrm{HBV}$ infection, constant activation of interleukin proteins and cytokine networks through the response of NF-KB can cause tissue damage and oncogenesis $[93,94]$.

\subsubsection{Specificity Protein 1}

One of the most studied transcription factors in HBV studies is Specificity protein 1 (Sp1), a Krüppel-like factor (a family of transcription factors with zinc finger domains) that plays critical roles in gene expression in early stages of development [95]. Sp1 is also associated with a range of cellular processes such as angiogenesis, apoptosis and the cell cycle [96]. Sp1 is comprised of three zinc finger domains (Figure 3A), which are located downstream of one DNA-binding domain within its protein structure, these domains are flanked by auxiliary domains responsible for oligomerization and inhibition. It should be noted that these functions are putative and detailed structural-functional studies will shed more light on Sp1's role in HBV replication [23,52,53]. Figure 3A represents the 
solution structures of three zinc finger domains determined using the nuclear magnetic resonance technique [52]. Sp1 has several binding motifs in the human genome, including GC-rich regions and CACCC motifs and can help regulate the expression of both TATA-containing and TATA-less genes [97-99].

In HBV, Sp1 has been demonstrated to bind to several sites in the HBV genome including the core promoter, the PreS1/S2 promoter and the ENII region $[13,23]$ and has been reported to regulate HBV gene expression during viral infection. In this study, the Sp1 binding regions in HBV were mapped by introducing single mutations in the putative binding regions (G-to-A at nucleotide 1748 and C-to-A at nucleotide 1630 respectively) and the plasmids containing the mutants were transfected into Huh7 hepatoma cells [23]. Both introduced mutations had caused a decrease in transcription of $C$ and the latter mutation caused a simultaneous increase in $S$ and $X$ transcription [23]. This study shows that Sp1 interaction with cccDNA has a direct impact on HBV replication.

\subsubsection{Chicken Ovalbumin Upstream Promoter Transcription Factor}

Chicken Ovalbumin Upstream Promoter Transcription Factor (COUP-TF) is also known to be an orphan nuclear receptor and is part of the steroid/thyroid family [100]. The COUP-TF contains a ligand-binding domain, two activation domains that allow for the binding of essential co-factors and a DNA-binding domain that contains two zinc finger domains (Figure 3B) $[39,101]$. The two C2H2 zinc fingers are found to be close to each other spatially. Typically, the COUP-TF dimerizes to recognize and bind the GGTCA half repeat motif. This motif has two of the same repeats separated by a variable six nucleotide gap [100,102]. The two-finger zinc finger domains work together to recognize and bind to the DNA, which is a characteristic of other steroid/thyroid hormone receptors [100]. DNA binding can only occur when the COUP-TF proteins are not bound to the receptor-ligand [100].

COUP-TF is primarily associated with the hormone response by both binding to secreted hormones and interacting with other hormone receptors such as the Retinoid $\mathrm{X}$ receptor and the thyroid hormone receptor $[13,103,104]$. It has additional roles in organ development, neural development, and cell migration/differentiation [105,106]. In terms of HBV replication, COUP-TF is known to repress transcription in HepG2 cells by interacting with the ENI element and represses $C$ and $S$ transcription levels [107]. There are also studies suggesting that COUP-TF is potentially able to repress ENII activity [108]. The binding to the ENI site is dependent on the levels/ratio of hepatocyte nuclear factor 4 present $(\mathrm{HNF} 4 \alpha)$, as these two transcription factors compete for binding to the promoter regions described [109].

\subsubsection{CCAAT Enhancer Binding Protein Family}

CCAAT is a binding motif found in promoter regions of various eukaryotic proteins. A family of proteins that bind this motif is called the CCAAT Enhancer Binding Protein (C/EBP) family and are characterized as having leucine zipper binding domains [110]. C/EBPs proteins (six members- $\mathrm{C} / \mathrm{EBP} \alpha-\mathrm{C} / \mathrm{EBP} \zeta$ ) either interact as heterodimers or homodimers to bind the CCAAT motifs in DNA [35]. C/EBP transcription factors are associated with functions in the liver that include metabolism, hormone control, and hepatocyte regeneration [111] as well as influence functions of myeloid-derived suppressor cells [112].

C/EBP can bind to the ENII site in the Pre-core promoter of the HBV genome in HepG2 cells which are facilitated by interactions with the HBx protein $[113,114]$. The binding of C/EBP can positively or negatively regulate transcription based on expression levels where low expression induces transcription, and higher levels are repressive [114,115]. In Huh7, HepG2 and HeLa cell lines, The C/EBP can also bind to the $S$ promoter to enhance transcription [116]. Researchers have studied how RNA may be able to affect virulence through interactions with C/EBP [117,118]. For example, Sarkar et al. [118] illustrated that microRNA-155, an RNA associated with the innate immune response, is capable of inhibiting $C / E B P-\beta$ and therefore causing a decrease in viral load. 


\subsubsection{Transcription Factor IIB}

Transcription Factor IIB (TFIIB) is a part of the transcription initiation complex in the host cells. It ensures proper orientation of the DNA-RNA duplex to facilitate RNA synthesis [119]. The active site of TFIIB contains zinc finger binding domains (with the amino acid structure of CXHXCXC) which help bind to promoter regions of DNA [59].

The HBx protein interacts with TFIIB protein facilitating viral replication, where HBx acts by first activating TFIIB, causing the transcription initiation complex to bind to the promoter regions $[60,120]$. Haviv et al. confirmed the direct binding of HBx with TFIIB using coimmunoprecipitation techniques [120] by demonstrating that compared to wild type, TFIIB zinc finger mutants were found to not coimmunoprecipitate with $\mathrm{HBx}$ confirming disruption of binding. This interaction is critical for the coactivation ability of HBx [121]. TFIIB can associate with HBx as well as with another RNA polymerase (RPB5), which upregulates viral RNA transcription levels and higher viral replication $[60,122]$.

\subsubsection{Zinc-Finger E-Box Binding Homeobox 2}

Zinc-finger E-box binding homeobox 2 (ZEB2) is a ubiquitous transcription factor that plays critical roles in TGF- $\beta$, and Bone Morphogenetic Protein (BMP) signaling pathways [123,124]. It is also crucial in embryonic development [125] and the development of the neural crest [126,127]. ZEB2 has two zinc finger clusters that bind to CACCT sequences and inhibit transcription [128,129]. Each of the two zinc finger clusters has three zinc finger domains, most having the C2H2 zinc finger motifs [128]. ZEB2 was identified as an HBV core promoter interacting protein in HepG2.2.15 and HepAD38 cell lines using Chromatin immunoprecipitation (ChIP) assays and was demonstrated to inhibit HBV replication [65].

\subsubsection{Tumor Protein 53}

Tumor protein 53 (also known as P53) is a crucial tumor suppressor protein that is involved with cell proliferation, cell death, DNA damage, oxidative stress, hypoxia, etc. and acts as a transcription factor for several genes including CDKN1A and BAX $[130,131]$. p53 binds DNA as homotetramer which binds to one DNA half-site called a response element (RRRCWWGYYY), therefore indicating that a full response element is bound by two homotetramers [130,132]. The homotetramer structure is facilitated by the tetramerization domain on the C-terminus of the protein [130]. The DNA-binding domain also contains two clusters of zinc fingers which each contain two zinc finger motifs [133].

p53 inhibits HBV replication by interacting with the ENII and the X promoter region [61-63]. However, HBx can alter the inhibitory effects of p53 by directly or indirectly interacting with p53 [134,135]. ChIP-sequencing experiments using HepG2 cells suggested that p53 had altered binding activity in the presence of HBx. Recruitment of host DNA is decreased by the disruption of P53-TBP/TFAP2A-RB1 protein complexes by HBx but the recruitment of host DNA is increased with p53 associated transcription factors such as Sp1 and c-JUN, which alters site binding in favor for HBV replication [135].

\subsubsection{Regulatory Factor Box 1}

Regulatory Factor Box 1 (RFX1) is a ubiquitous transcription factor that regulates several genes such as MHC class II proteins, interleukin-5 receptor $\alpha 5$, and c-Myc indicating its importance in the host immune response and cell proliferation [136]. RFX1 binds to DNA using a winged-helix (helix-turn-helix) sequence and binds DNA in a sequence-specific manner (GTNRCC(0-3N)RGYAAC) [137].

RFX1 is able to inhibit HBV replication by binding to the ENI site and core promoter [48-50]. Julien et al. employed antisense oligonucleotides to inhibit RFX1, allowing for HBV surface antigen expression in HepG2 cell lines [138]. Interestingly, ENI binding does not occur in non-hepatic cell lines, suggesting that RFX1 is interacting with liver-enriched transcription factors to inhibit HBV replication 
at this site [138]. In order to bind the core promoter of the HBV genome, RFX1 binds to a factor called the c-Myc Intron Binding Protein 1 (MIBP1) [49].

\subsubsection{Homeobox A10}

Homeobox A10 (HOXA10) is a transcription factor critical in processes such as endometriosis, embryogenesis, and cell differentiation [139-141]. HOXA10 is able to bind to DNA (AA(AT)TTTTATTAC) through its homeobox domain; a helix-turn-helix motif that is abundantly found in prokaryotic DNA-binding proteins [142].

HOXA10 can inhibit HBV replication through binding of the $X$ and ENI regions of the genome and has been confirmed in HepG2, HepG2.2.15, HepG2-NTCP, primary hepatocytes and mice [40]. Interestingly, binding of HOXA10 to ENI competes for binding with Signal Transducer and Activator of Transcription 3 (STAT3), disrupting STAT3 initiated transcription [40]. Disruption of initiation via STAT3 also occurs indirectly as HOXA10 interacts with the MAPK/STAT3 pathway. The recruitment of small heterodimer partner (SHP) preventing STAT3 phosphorylation that allows for the functional conformation [40].

\subsubsection{Octamer Binding Protein 1}

Octamer binding protein 1 (Oct1) is a ubiquitous transcription factor that recognizes a DNA sequence called the octamer motif (ATGC(A/TA)AAT). It can also recognize similar sequences with the addition of a second Oct1 protein $[143,144]$. Oct1 has a DNA-binding domain called the POU domain that contains a POU-specific domain and a POU-homeodomain [145]. Oct1 is critical for a variety of biological processes such as T-cell differentiation, tissue development, and oxidative and metabolic stress responses [146-148].

Oct1 can bind to the PreS1 promoter in the HBV genome in HepG2 cells and HeLa cells and works with HNF1 as an essential co-activator to activate transcription [46]. Additionally, the HBx protein interacts with the Oct-1 protein that is in complex with other preinitiation factors in order to bind the U6 snRNA promoter and initiate transcription [149].

\subsubsection{Nuclear Respiratory Factor 1}

Nuclear respiratory factor 1 (NRF1) is a ubiquitous transcription factor related to mitochondrial biogenesis and function and plays a role in apoptosis through the mitochondrial associated genes [150-152]. NRF1 interacts with the consensus DNA sequence (YGCGCAYGCGCR) DNA via its two zinc finger domains $[153,154]$. NRF1 has been shown to recruit Peroxisome proliferator-activated receptor-gamma coactivator (PGC-1 $\alpha$ ) but this is not essential for binding to the DNA [45].

Although the endogenous level of NRF1 is not limiting to HBV replication, it has been demonstrated to bind to the $X$ promoter and activated gene transcription as determined in HepG2 cell lines [44].

\subsubsection{Signal Transducer and Activator of Transcription 1}

Signal Transducer and Activator of Transcription 1 (STAT1) is a ubiquitous protein, which is highly expressed in lymphocytes. It is involved with processes such as infection defense, immune tolerance, cell proliferation and apoptosis $[155,156]$. STAT proteins bind as dimers or higher-order structures in order to bind specific DNA sequences (NATTTCCNGGAAAT) [157,158].

Stat 1 binds to the ENI/X promoter region of the genome [55]. However, HBx actively prevents STAT1 activity by disrupting its ability to activate interferons. Type I interferon induction is blocked upstream in the signaling pathway as seen in Hep2.2.15 cell lines [159]. HBx is able to prevent interferon transcription by inhibiting the nuclear translocation of STAT1 [54]. It should be noted that HBx can disrupt numerous upstream factors such as kinase epsilon (IKKE) and interferon regulatory factor 3 (IRF3) [54]. 


\subsubsection{Signal Transducer and Activator of Transcription 3}

Signal Transducer and Activator of Transcription 3 (STAT3) is also a ubiquitous transcription factor that is a part of the JAK/STAT pathway. STAT3 influences the host immune response, cell cycle regulation, growth factors regulation, cell transformation, and many other cellular processes [160-162]. In order to bind DNA, Tyr-709 of STAT3 is phosphorylated followed by the formation of a homodimer via its SH2 domain before entering the nucleus and binding to the consensus sequence TTCCCGGAA [163].

STAT3 can also promote HBV replication by interacting with HNF3 that is bound to the ENI site of the HBV genome $[25,56]$. The activation of STAT3 and an increase in STAT3 activator IL-6 was seen in studies with HepG2 and HepG2.2.15 cells. The silencing of STAT3 via shRNA leads to inhibition of HBV replication in both cell lines and mice [56].

\subsubsection{Activator Protein 1}

Activator protein 1 (AP-1), a ubiquitous transcription factor, is associated with cellular processes such as cell proliferation, apoptosis, cell differentiation and angiogenesis [164-166]. AP-1 refers to dimeric complexes that include transcription factor families such as JUN, FOS, ATF, and MAF. Both the DNA binding and dimerization of these AP-1 complexes are facilitated by bZIP leucine-zipper domains [164]. Once dimerized the complex can then recognize the DNA consensus sequence TGA(G/C)TCA [167].

AP-1 is activated by the JNK pathway [168] and can also be activated indirectly by HBx which binds to Jak1 or JAB1 in vivo $[134,169]$. Once activated, AP-1 is able to activate the PreS2/S region of the HBV genome as determined in HepG2 and HeLa cells $[34,170]$.

\subsubsection{Prospero-Related Homeobox Protein 1}

Proper-related homeobox protein (PROX1) is also a ubiquitous transcription factor that influences embryonic development, cell fate, neural and tissue development, and regulates the circadian rhythm [171-173]. DNA binding is facilitated through its homeodomain which has a helix-loop-helix-turn-helix structure which can bind to the consensus sequences (A/C) AAGN(C/G/T) or $\mathrm{CA}(\mathrm{C} / \mathrm{G} / \mathrm{T}) \mathrm{NN}(\mathrm{C} / \mathrm{G}) \mathrm{Y}[171,174]$.

PROX1 interacts with the DNA binding and ligand-binding domain of the liver receptor homolog-1 (LRH-1) [175]. When in complex with LRH-1, ENII downregulation occurs. Overall, Prox1 has been identified to bind to the ENI, ENII and PreS1 promoter and repress HBV replication. Interestingly, PROX1 can also interact with HNF1 $\alpha$ and disrupt Sp1 activity when studied in HepG2, Huh7 and HeLa cells [174].

\subsubsection{TATA Box Protein}

TATA box protein (TBP) is a ubiquitous transcription factor that is crucial for host transcription initiation and is functional once bound to the transcription factor IID (TFIID) complex [176]. The TBP has a saddle-like structure in its DNA-binding domain that allows binding to the TATA consensus sequence (TATAa/tAa/t) [177,178].

The TBP protein interacts with TATA-like sequences in the PreS2/S promoter region in the HBV genome and enhances HBV replication as studied in HepG2 and Huh7 cell lines [58]. The HBx protein has also been shown to interact with TBP on an ATP-dependent basis in vitro to further facilitate HBV replication [179].

\subsubsection{Yin Yang 1}

Yin Yang 1 (YY1) is a ubiquitous transcription factor that has roles in development, cell differentiation, proliferation and apoptosis $[180,181]$. YY1 binds DNA through its Zinc finger motifs and recognizes the DNA sequence CGCCATNTT $[180,182]$. 
YY1 has been shown to bind to cccDNA in HepG2 cell lines, binding to an integration sequence next to the direct repeat region 1 (DR1) in the HBV genome $[55,64,183]$. However, this binding does not affect HBV transcription but instead has a role in the integration of the HBV genome into the host genome [184]. Transcriptional activity is not directly with the HBV genome. Studies have indicated that YY1 regulates other signaling pathways that facilitate HBV replication. Shang et al. discovered that $Y Y 1$ activates the sex-determining region $Y$ box 4 protein in HepG2 cells with opposing results in control cells, suggesting a role in HBV replication [185].

\subsubsection{Activating Transcription Factor 2}

Activating Transcription Factor 2 (ATF2) is critical for biological processes including cell proliferation, inflammation, apoptosis, neurological development and skeletal remodeling, acetyltransferase activity, and DNA damage [186-188]. ATF2 binds to the cAMP response element (cre) with the consensus sequence TGACGTCA with its C-terminal DNA-binding domain which contains a bZip leucine zipper motif [189]. It can also bind to the AP-1 consensus sequence [190].

ATF2 competitively binds with AP-1 to the ENI promoter region and is able to repress the transcription of $\mathrm{X}$ gene in HepG2 cells. Choi et al. determined that with transfection of a vector containing AFT2 into HepG2 cells caused a decrease in JUN/FOS binding to the ENI site [33].

\subsubsection{0. cAMP Response Element-Binding Transcription Factor}

cAMP response element-binding transcription factor (CREB) is a ubiquitous transcription factor that is associated with cellular processes gluconeogenesis, lipid metabolism, cell proliferation and neuronal plasticity [191-193]. CREB binds to the cre element within the genome via its bZip motif [194].

Faktor et al. demonstrated that CREB interacts with the ENI region of HBV [37]. Subsequent studies by Kim et al. suggested that the cre sequence in HBV is highly conserved and interaction of HBV genome with CREB is essential for HBV replication [36]. CREB can also facilitate the binding of the CREB-regulated transcriptional coactivator 1 protein (CRTC1) to the PreS2/S site and positively influence HBV transcription. Contrarily, inactive CRT1 protein at high levels was shown to inhibit HBV transcription in HepG2 cells [195].

\subsubsection{Small Heterodimer Partner}

Small heterodimer partner (SHP) is an orphan nuclear receptor associated with the regulation of bile acid synthesis, lipid metabolism, cancer development, microRNA expression and innate immune system [196-199]. Interestingly, SHP does not contain a DNA-binding domain, suggesting that it acts as a cofactor, facilitating binding with HBV components [51].

HNF $4 \alpha$ bound to SHP was demonstrated to repress HBV replication in HepG2 cells as well as non-hepatic cell lines [51]. Reese et al. concluded that SHP and its corepressor FXR $\alpha$ have a limited role in HBV replication [200]. Additionally, SHP is also recruited by HOXA10, leading to suppression of p38 MAPK/STAT3 pathway and HBV replication [40]. 


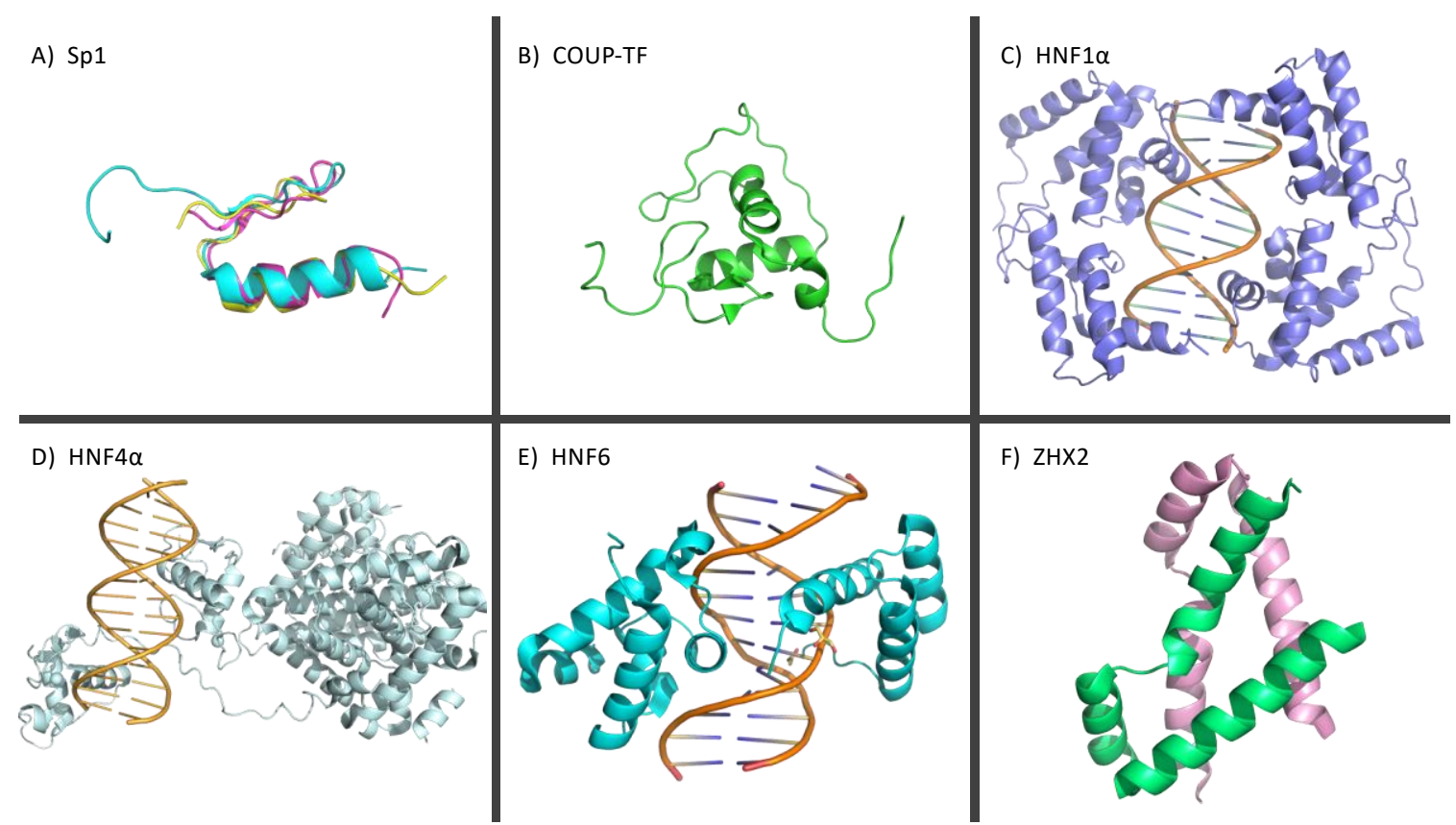

Figure 3. An overview of high-resolution structures of transcription factors. (A) An overlay of high-resolution structures of three zinc finger domains of Sp1 [53]. (B) A structure of COUP-TF zinc finger domain [pdb: 2EBL]. (C,D) High-resolution structures of HNF1 $\alpha$ [201] and HNF4 $\alpha$ [202] bound to the major groove of DNA. In both cases, cccDNA DNA sequences (5'-GTTAATNATTAAC-3' recognized by HNF $1 \alpha$ and $5^{\prime}$-CAGAGGNCAAAGTCCA- $3^{\prime}$ by HNF4 $\alpha$ ) were used to calculate 3 dimensional structures employing 3D-DART web server [203]. (E) High-resolution structure of mouse HNF-6 $\alpha$ DNA-binding domain bound, which is identical to human HNF- $6 \alpha$ DNA-binding, with transthyretin (TTR) promoter [204]. (F) Dimeric structure of homeodomain 2 of ZHX2 protein [205].

\subsection{Liver-Enriched Transcription Factors}

HBV is a hepatotropic virus that gains entry into hepatocytes via the host's bile salt receptorsodium taurocholate co-transporting polypeptide (NTCP) in complex with the epidermal growth factor, when interacting with the pre-S1 domain of the HBV large envelope protein [14,206-209]. As such, liver-specific transcription factors have been implicated in supporting HBV's replication cycle.

\subsubsection{Hepatocyte Nuclear Factor $1 \alpha$}

Hepatocyte nuclear factor 1 alpha (HNF1 $\alpha)$ is a part of the HNF1 sub-family [210]. HNF1 $\alpha$ has an N-terminal POU domain, a DNA binding homeodomain and an N-terminal dimerization domain [211]. The HNF1 $\alpha$ protein interacts with other HNF1 family proteins to form homodimers or heterodimers [212,213]. The homodimer/heterodimer structure allows for binding to the DNA which is facilitated by the POU domain (Figure 3C) [210,211]. HNF1 $\alpha$ regulates tissue development and associated processes, maintains amino acid levels, and gluconeogenesis [214-216].

The POU homeodomain in HNF1 $\alpha$ is suggested to bind to the PreS1 promoter region of the HBV genome [46]. Additionally, HNF1 $\alpha$ interacts with $\mathrm{HBx}$, the core promoter and the ENII element $[71,72,217]$. HNF1 $\alpha$ 's interaction with the ENII element is crucial for an efficient $\mathrm{HBV}$ replication in hepatic cell lines; activation of the ENII element is prevented if the HNF1 $\alpha$ is knocked down [218]. However, in vivo studies suggest that the absence of HNF1 $\alpha$ does not prevent HBV replication [218]. Furthermore, high HNF1 $\alpha$ levels enhance expression of the NF-kB transcription factor which in turn inhibits HBV genome transcription [219]. Additionally, it was demonstrated that its overexpression leads to inhibition of HBV gene expression, whereas its absence enhances expression [219]. 


\subsubsection{Hepatocyte Nuclear Factor 3}

Hepatocyte nuclear factor 3 (HNF3 also known as FOXA) encompasses a subfamily of transcription factors that includes HNF3 $\alpha, \beta$ and $\gamma$ [220]. HNF3 transcription factors contain a conserved winged-helix DNA-binding region. The third helical structure in this domain recognizes the genomic DNA and binds within the major groove of the DNA helix [220]. The HNF3 proteins primarily regulate metabolic cellular processes such as carbohydrate and lipid metabolism, and fatty acid oxidation [221-223].

The HNF $3 \alpha, \beta$ and $\gamma$ proteins were shown to bind with ENI and ENII and increase their activity in Huh7, HepG2 and HeLa cell lines [38,73]. Additionally, HNF3 interacts with the PreS1 promoter region in HepG2 cells [74]. However, contradicting evidence has emerged in terms of how HNF3 can regulate the activity. HBV replication studies in HepG2 cells indicated enhanced viral gene expression while expression in SK-Hep1 cells suggested inhibited HBV replication [224,225], highlighting the need for additional mechanistic studies.

It is hypothesized that HNF3 can unwind HBV cccDNA and facilitate viral transcription by allowing the binding of other transcription factors [226]. Future studies on the HNF3 function will provide a more in-depth understanding of HNF3's role in HBV replication.

\subsubsection{Hepatocyte Nuclear Factor $4 \alpha$}

Hepatocyte nuclear factor $4 \alpha$ (HNF4 $\alpha$ ) is a nuclear receptor that regulates HBV transcription [227]. Similar to HNF1 $\alpha$, HNF $4 \alpha$ contains a POU domain consisting of zinc finger regions that allow for DNA binding (Figure 3D) [228]. HNF4 $\alpha$ is associated with lipid and carbohydrate metabolism, inflammation as well as embryogenesis [229-232]. Although found in other cell types, HNF4 $\alpha$ is expressed in hepatocytes and is upregulated upon HBV infection [233]. HNF4 $\alpha$ is a positive regulator of HBV infection that is recognized to interact with the ENI, ENII (in Huh7 cells) and preS1 regions (HepG2 cells) [72,75-77]. Researchers have explored the potential of reducing infection by lowering HNF4 $\alpha$ levels in mice, which revealed that siRNA knockdown of HNF $4 \alpha$ prevents HBV replication and reduced pre-genomic RNA levels, but also impaired glucose homeostasis and growth of the cells [218,234]. Wang et al. demonstrated that estrogen receptor alpha (ER $\alpha)$, when bound to $\mathrm{HNF} 4 \alpha$, leads to lower expression levels of HBV genes [235]. The binding of ER $\alpha$ was confirmed to affect the binding affinity of HNF $4 \alpha$ for the ENI site and is a proposed mechanism for viral load and infection incidence disparity between males and females [235].

\subsubsection{Hepatocyte Nuclear Factor 6}

Hepatocyte nuclear factor 6 (HNF6) is present in various cell types such as pancreatic cells and the gallbladder, but the highest levels can be found in hepatocytes [236]. HNF6 contains two DNA-binding domains known as the homeodomain and single cut domain, where the homeodomain primarily binds the DNA and the single cut domain binds co-activating proteins for initiation of transcription [237]. Figure 3E represents a high-resolution structure of mouse HNF6 bound with transthyretin promoter [204]. It plays key roles in many critical cellular processes such as pancreas development, suppression of cancer cell growth, cell differentiation, morphogenesis, lipid metabolism, and growth hormone production [238-242].

Hao et al. demonstrated that HNF6 interacts with HBV S promoter and its upregulation leads to suppression of HBV replication and reduced viremia, while HNF6 knockout increased viral loads using HepG2, Huh7 and human embryonic kidney 293T cells [78]. HNF6 induction by upstream proteins has also been confirmed to affect HBV replication. Lahuna et al. suggested that in mice, high levels of CYP2C12 causes upregulation of HNF6, therefore causing suppression of HBV replication [243].

\subsubsection{Peroxisome Proliferator-Activated Receptor $\alpha$}

Peroxisome Proliferator-Activated Receptor $(\operatorname{PPAR} \alpha)$ is a liver-enriched nuclear receptor that is associated with beta-oxidation, inflammation, gluconeogenesis, ketone synthesis, fatty acid 
catabolism, and lipoprotein assembly [244-247]. PPAR $\alpha$ forms a heterodimer with retinoid X receptor $(R X R \alpha)$ and interacts with DNA via its two zinc finger motifs in the DNA-binding domain [248]. The PPAR $\alpha-R X R \alpha$ complex activates the ENI, Core and PreS2/S promoter in both hepatic and non-hepatic cell lines $[80,249,250]$. The activation of these sites via PPAR $\alpha-R X R \alpha$ can be further enhanced by the interaction of PGC-1 $\alpha$ with this complex [251]. Hu et al. suggested that microRNA-141 interacts with PPAR $\alpha$ and inhibits HBV replication in HepG2 cells [252].

\subsubsection{Retinoid X Receptor $\alpha$}

Retinoid $X$ Receptor $(R X R \alpha)$ is also a liver-enriched nuclear protein and interacts with other nuclear factors such as COUP-TF, PPAR $\alpha$, and PGC- $1 \alpha$ to facilitate binding of genomic DNA and improve transcriptional activation $[103,248,251]$. It also forms a heterodimer complex with thyroid hormone receptors and retinoic acid receptors [253]. RXR $\alpha$ binds to DNA as a homodimer through $\mathrm{RXR} \alpha$ 's DNA-binding domain contains two zinc fingers and three $\alpha$ helices. The C-terminal $\alpha$ helices control the DNA-binding function which recognizes half-sites with the sequence AGGTCA [254].

The RXR $\alpha$-PPAR $\alpha$ complex is capable of binding the ENI, core, and S promoter in the HBV genome [81,107]. This complex was shown to enhance HBV replication in HepG2-NTCP cells and other models such as primary Tupaia hepatocytes [255]. The knockdown of RXR $\alpha$ expression decreased infection and cccDNA level as determined by quantitative PCR [255].

\subsubsection{Farsenoid X Receptor $\alpha$}

Farsenoid $X$ Receptor $\alpha(F X R \alpha)$ is another liver-enriched nuclear receptor and is a part of the nuclear receptor superfamily of ligand-activated transcription factors [256]. It is activated primarily by bile acids [257] and is associated with cellular processes such as lipid and glucose metabolism as well as liver regeneration [256,258-260]. Besides its ligand-binding domain for interacting with bile acids, FXR $\alpha$ has a conserved N-terminal DNA-binding domain that interacts with specific half nuclear receptor sites in the genome (AGGTCA) [261,262]. The FXR $\alpha-R X R \alpha$ complex can bind to the basal core promoter and the ENII site and activate viral transcription as determined using quantitative PCR $[66,67]$. Moreover, the FXR $\alpha-P G C-1 \alpha$ complex has been shown to enhance HBV replication [263]. By using a microRNA-1, FXR $\alpha$ expression can be silenced and allow for the enhancement of HBV replication in HepG2 and Huh7 cell lines [264].

\subsubsection{Zinc Finger and Homeoboxes 2}

Zinc finger and homeoboxes 2 (ZHX2) is also a liver-enriched transcriptional repressor in adult hepatocytes and a tumor suppressor $[265,266]$. It is important for hepatocyte gene regulation and liver development and plays roles in renal cancer and stem cell differentiation [267-270]. ZHX2 contains four homeodomains and two $\mathrm{C} 2 \mathrm{H} 2$ zinc finger motifs that allow for DNA binding causing transcriptional repression as both a homodimer (Figure 3F) or a heterodimer when bound with ZHX1 [265,271].

ZHX2 suppresses HBV replication by inhibiting the activity of the X, C and PreS2 promoters [82]. Additionally, ZHX2 also interacts with the A subunit of NF-Y and prevents its DNA binding ability, potentially effecting the recruitment of NF-Y during HBV replication [272]. Interestingly, recent studies demonstrate that HBV infection leads to an over-expression of microRNA-155 which suppresses ZHX2 expression, ultimately accelerating hepatocellular carcinoma progression [273].

\subsubsection{Krüppel-Like Factor 15}

Krüppel-like factor (KLF15), a liver-enriched transcription factor is associated with cellular functions such as glucose uptake and adipogenesis [274-276]. KLF15 contains three C2H2 zinc fingers that facilitate DNA binding to specific GC rich promoter regions (GGGGNGGNG), similar to Sp1 [95,277].

Using ChIP assays, KLF15 has been shown to bind to the S and C promoters and increase HBV transcription [68]. KLF15 increases surface antigen levels by 7-fold in HepG2 cells and 20-fold in 
Huh7 cell lines. In mice, the use of non-functional KLF15 mutants caused a significant reduction in viral load [68]. Due to the similarities between KLF15 and Sp1, it is hypothesized that the two work synergistically as the $\mathrm{S}$ and C promoter regions to facilitate HBV replication [68].

\subsubsection{Liver Receptor Homolog 1}

Liver receptor homolog 1 (LRH-1) also known as the Fetoprotein transcription factor is associated with liver development and hormonal responses [278,279]. LRH-1 contains both a zinc finger DNA-binding domain and a ligand-binding domain [280]. The DNA-binding domain of LRH-1 recognizes the sequence of YCAAGGYCR while the ligand-binding domains facilitate the binding of other factors such as PROX1 [281,282].

It has been demonstrated that LRH-1 binds and activates ENII at two different sites in the HBV genome and activates transcriptional activity. It has also been found to interact with PROX1, HNF1 and HNF4 $[69,70]$. Specifically, it was suggested that a stronger activation of the ENII site occurs by a synergistic effect of LRH-1 and HNF1 transcription factors [70].

\section{Conclusions}

Many cellular processes modulate the HBV minichromosome (i.e., HBV cccDNA) activity such as cccDNA histone acetylation, epigenetic modifications of the cccDNA and activation of signal transduction pathways such as immune response pathways. For example, IFN- $\alpha$ is an approved treatment for chronic HBV infection, and it was recently found to decrease the number of histones that bind onto the cccDNA, causing repression of HBV replication [55]. Another study by Liu et al. also manipulated the cccDNA by using histone deacetylase (HDAC) inhibitors to disrupt the cccDNA histone acetylation sites. Interestingly, in this study, the HDAC inhibitors increased replication [283]. As the epigenetics has a large regulatory impact on viral replication, specific targeting of epigenetic modifications may be a potential strategy for cccDNA control or elimination.

Although we have gained an understanding of many aspects of HBV life-cycle, large gaps in knowledge remain in many aspects of HBV replication mechanisms, particularly the HBV cccDNA-host protein interplay. Current oral antivirals (i.e., reverse transcriptase or polymerase inhibitors) suppress HBV replication at downstream stages of replication. These nucleos $(t)$ ide analogs are competitive inhibitors of the HBV polymerase and can downregulate viral replication [90], but the longevity and stability of the cccDNA in the host nucleus allows for recurrence of viremia if therapy is stopped [15]. Furthermore, the viral genome integration into the host genome can contribute to the pool of proteins, putting additional pressure on the immune system, as well as host pathway disruption and carcinogenic potential depending on the site of integrations [8,284]. As the integration of HBV poses another layer of difficulty for effective HBV therapeutics, new approaches may be needed, including other new and emerging technologies in order to completely eradicate HBV.

Clustered regularly interspaced short palindromic repeats (CRISPR) technology has been recently suggested for therapeutic use. CRISPR/Cas9, an accurate DNA editing technology can be used to mutate the cccDNA in order to destabilize the structure [285]. A recent study by Schiwon et al. demonstrated that the CRISPR/Cas9-based system is capable to inhibit HBV replication [286]. However, the low concentrations of ccCDNA in patients limit the effective targeting of CRISPR/Cas9 system, analysis of treatment, and potential off-targeting effects that affect the successful implementation of CRISPR/Cas9 system [285].

Gene silencing and/or degradation of mRNA through RNA interference (RNAi) has the potential to diminish cccDNA levels. However, much like CRISPR/Cas9, the accuracy of targeting is a large concern for use as a therapeutic. Furthermore, delivery and the stability of RNAi is also a challenge. One example of how this technology may be implemented is using viral delivery systems that may aid in the deployment of RNAi technologies and ensure accurate targeting to hepatocytes $[287,288]$. It has been suggested that this technology may be successful as a combinational therapy in order to achieve a more effective outcome [288]. Additionally, the use of N-acetylgalactosamine, a promising 
technology for liver targeting, in order to deliver RNAi oligonucleotides, can potentially increase the ability for RNAi technology to be taken up into hepatocyte cells without the need of a viral-based delivery mechanism [289].

Finally, the development of therapies that modify the epigenetic profiles of the cccDNA in order to disrupt the structure of the genome can prove to be an effective way of preventing viral load. HBV cccDNA potentially has three methylation regions (CpG islands) which overlap with the ENI, X and core promoter regions [290,291]. Hypermethylation of the CpG regions has been associated with low HBV genomic transcription. Additionally, with methylation events there is a change in acetylation events, leading to the modification of interactions of the cccDNA histone proteins. The general organization of the cccDNA has been described by Tropberger et al. which indicates the potential for epigenetic manipulation [292]. Insights into the epigenetic regulation of the cccDNA and its contributions to HBV replication could aid the development of epigenetic drugs for the treatment of HBV replication. For example, the histone deacetylase SIRT3 has been illustrated to cause a decrease in cccDNA replication. It is hypothesized that SIRT3 manipulates the recruitment of other methyltransferases and therefore changes the overall epigenetic pattern, such that cccDNA is no longer being recognized by host transcription factors [292]. Multiple studies have demonstrated that the histones that package the cccDNA of HBV can have modified activity which can affect overall transcriptional ability $[3,9]$. Using a specific epigenetic modifier that decreases the stability of the cccDNA, it could be possible to inhibit the overall replication of the virus. Disrupting the stability of cccDNA will also prevent the ability of the transcription factors to bind [293]. Manipulating the structure of the cccDNA might drastically affect the ability of DNA-protein interactions, and therefore for necessary transcription factors required for viral replication. However, this therapy would only prevent viral load and combination therapy may aid with complete eradication of HBV from the patient(s) [290].

The current review provides an overview of many transcription factors that can promote and inhibit viral transcription. As pointed out in this review, many transcription factors can promote and inhibit transcription. While such functions could be related to concentration-dependence and/or experimental restraints, it is likely that various protein domains or conformations may also influence these differing functions. These structure-function relationships according to these domains can then be targeted as a potential therapeutic candidate. Imaging methods and binding affinity studies can provide detailed information on the activity as well as the binding characteristics of the interactions. To the best of our knowledge current literature lacks studies of high-resolution structural information on cccDNA-host transcription factor complexes. Using techniques such as small-angle X-ray scattering, cryo-electron microscopy, nuclear magnetic resonance and X-ray crystallography, structural information on individual biomolecules and their complexes can be obtained [53,294-297]. With such techniques, a better understanding of viral DNA-host protein interactions can be achieved, provide further insights into the HBV replication process, and ultimately guide the development of new therapeutic strategies.

Author Contributions: K.L.T. wrote the initial draft of the manuscript. V.M.-S., M.D.B., C.S.C. and T.R.P. helped with further development of the manuscript. All authors have read and agreed to the published version of the manuscript.

Funding: K.L.T. is supported by the NSERC CREATE program. V.M.-S. acknowledges funding from the Canadian Hepatitis C Network. M.D.B. is supported by the Alberta Innovates Strategic Research Projects grants. T.R.P. is a Canada Research Chair in RNA and Protein Biophysics. C.S.C. and T.R.P. acknowledge Alberta Innovates Strategic Research Projects grant.

Conflicts of Interest: The authors declare no conflicts of interest.

\section{References}

1. WHO. Global Hepatitis Report 2017; World Health Organization: Geneva, Switzerland, 2017; p. 7.

2. Cheng, Z.; Zhi, X.; Sun, G.; Guo, W.; Huang, Y.; Sun, W.; Tian, X.; Zhao, F.; Hu, K. Sodium selenite suppresses hepatitis B virus transcription and replication in human hepatoma cell lines. J. Med. Virol. 2016, 88, 653-663. [CrossRef] 
3. Kim, D.H.; Kang, H.S.; Kim, K.H. Roles of hepatocyte nuclear factors in hepatitis B virus infection. World J. Gastroenterol. 2016, 22, 7017-7029. [CrossRef]

4. Lu, C.C.; Yen, T.S. Activation of the hepatitis B virus S promoter by transcription factor NF-Y via a CCAAT element. Virology 1996, 225, 387-394. [CrossRef] [PubMed]

5. Moolla, N.; Kew, M.; Arbuthnot, P. Regulatory elements of hepatitis B virus transcription. J. Viral. Hepat. 2002, 9, 323-331. [CrossRef] [PubMed]

6. Pan, C.Q.; Duan, Z.; Dai, E.; Zhang, S.; Han, G.; Wang, Y.; Zhang, H.; Zou, H.; Zhu, B.; Zhao, W.; et al. Tenofovir to Prevent Hepatitis B Transmission in Mothers with High Viral Load. N. Engl. J. Med. 2016, 374, 2324-2334. [CrossRef] [PubMed]

7. Gehring, A.J.; Protzer, U. Targeting Innate and Adaptive Immune Responses to Cure Chronic HBV Infection. Gastroenterology 2019, 156, 325-337. [CrossRef]

8. Tu, T.; Budzinska, M.A.; Vondran, F.W.R.; Shackel, N.A.; Urban, S. Hepatitis B Virus DNA Integration Occurs Early in the Viral Life Cycle in an In Vitro Infection Model via Sodium Taurocholate Cotransporting Polypeptide-Dependent Uptake of Enveloped Virus Particles. J. Virol. 2018, 92. [CrossRef]

9. Lucifora, J.; Protzer, U. Attacking hepatitis B virus cccDNA-The holy grail to hepatitis B cure. J. Hepatol. 2016, 64, S41-S48. [CrossRef]

10. Lucifora, J.; Xia, Y.; Reisinger, F.; Zhang, K.; Stadler, D.; Cheng, X.; Sprinzl, M.F.; Koppensteiner, H.; Makowska, Z.; Volz, T.; et al. Specific and nonhepatotoxic degradation of nuclear hepatitis B virus cccDNA. Science 2014, 343, 1221-1228. [CrossRef]

11. Beck, J.; Nassal, M. Hepatitis B virus replication. World J. Gastroenterol. 2007, 13, 48-64. [CrossRef]

12. Latchman, D.S. Transcription factors: An overview. Int. J. Biochem. Cell Biol. 1997, 29, 1305-1312. [CrossRef]

13. Quasdorff, M.; Protzer, U. Control of hepatitis B virus at the level of transcription. J. Viral Hepat. 2010, 17, 527-536. [CrossRef] [PubMed]

14. Yan, H.; Zhong, G.; Xu, G.; He, W.; Jing, Z.; Gao, Z.; Huang, Y.; Qi, Y.; Peng, B.; Wang, H.; et al. Sodium taurocholate cotransporting polypeptide is a functional receptor for human hepatitis $\mathrm{B}$ and D virus. Elife 2012, 1, e00049. [CrossRef] [PubMed]

15. Iwamoto, M.; Saso, W.; Sugiyama, R.; Ishii, K.; Ohki, M.; Nagamori, S.; Suzuki, R.; Aizaki, H.; Ryo, A.; Yun, J.H.; et al. Epidermal growth factor receptor is a host-entry cofactor triggering hepatitis B virus internalization. Proc. Natl. Acad. Sci. USA 2019, 116, 8487-8492. [CrossRef]

16. Li, H.C.; Huang, E.Y.; Su, P.Y.; Wu, S.Y.; Yang, C.C.; Lin, Y.S.; Chang, W.C.; Shih, C. Nuclear export and import of human hepatitis B virus capsid protein and particles. PLoS Pathog. 2010, 6, e1001162. [CrossRef] [PubMed]

17. Nassal, M. Hepatitis B viruses: Reverse transcription a different way. Virus Res. 2008, 134, 235-249. [CrossRef]

18. Seeger, C.; Mason, W.S. Hepatitis B virus biology. Microbiol. Mol. Biol. Rev. 2000, 64, 51-68. [CrossRef]

19. Yang, H.C.; Kao, J.H. Persistence of hepatitis B virus covalently closed circular DNA in hepatocytes: Molecular mechanisms and clinical significance. Emerg Microbes Infect. 2014, 3, e64. [CrossRef]

20. Laras, A.; Koskinas, J.; Dimou, E.; Kostamena, A.; Hadziyannis, S.J. Intrahepatic levels and replicative activity of covalently closed circular hepatitis B virus DNA in chronically infected patients. Hepatology 2006, 44, 694-702. [CrossRef]

21. Kao, J.H. Molecular epidemiology of hepatitis B virus. Korean J. Intern. Med. 2011, 26, 255-261. [CrossRef]

22. Heermann, K.H.; Goldmann, U.; Schwartz, W.; Seyffarth, T.; Baumgarten, H.; Gerlich, W.H. Large surface proteins of hepatitis B virus containing the pre-s sequence. J. Virol. 1984, 52, 396-402. [CrossRef]

23. Li, J.; Ou, J.H. Differential regulation of hepatitis B virus gene expression by the Sp1 transcription factor. J. Virol. 2001, 75, 8400-8406. [CrossRef]

24. Liang, T.J. Hepatitis B: The virus and disease. Hepatology 2009, 49, S13-S21. [CrossRef] [PubMed]

25. Quarleri, J. Core promoter: A critical region where the hepatitis B virus makes decisions. World J. Gastroenterol. 2014, 20, 425-435. [CrossRef] [PubMed]

26. Tang, H.; Delgermaa, L.; Huang, F.; Oishi, N.; Liu, L.; He, F.; Zhao, L.; Murakami, S. The transcriptional transactivation function of $\mathrm{HBx}$ protein is important for its augmentation role in hepatitis B virus replication. J. Virol. 2005, 79, 5548-5556. [CrossRef] [PubMed]

27. Lucifora, J.; Arzberger, S.; Durantel, D.; Belloni, L.; Strubin, M.; Levrero, M.; Zoulim, F.; Hantz, O.; Protzer, U. Hepatitis B virus $X$ protein is essential to initiate and maintain virus replication after infection. J. Hepatol. 2011, 55, 996-1003. [CrossRef] [PubMed] 
28. Murakami, S. Hepatitis B virus X protein: A multifunctional viral regulator. J. Gastroenterol. 2001, 36, 651-660. [CrossRef] [PubMed]

29. Liang, T.J. Virology: The X-Files of hepatitis B. Nature 2016, 531, 313-314. [CrossRef]

30. Decorsiere, A.; Mueller, H.; van Breugel, P.C.; Abdul, F.; Gerossier, L.; Beran, R.K.; Livingston, C.M.; Niu, C.; Fletcher, S.P.; Hantz, O.; et al. Hepatitis B virus X protein identifies the Smc5/6 complex as a host restriction factor. Nature 2016, 531, 386-389. [CrossRef] [PubMed]

31. Belloni, L.; Pollicino, T.; De Nicola, F.; Guerrieri, F.; Raffa, G.; Fanciulli, M.; Raimondo, G.; Levrero, M. Nuclear HBx binds the HBV minichromosome and modifies the epigenetic regulation of cccDNA function. Proc. Natl. Acad. Sci. USA 2009, 106, 19975-19979. [CrossRef] [PubMed]

32. Meier-Stephenson, V.; Bremner, W.; Dalton, C.; van Marle, G.; Coffin, C.; Patel, T. Comprehensive Analysis of Hepatitis B Virus Promoter Region Mutations. Viruses 2018, 10, 603. [CrossRef] [PubMed]

33. Choi, C.Y.; Choi, B.H.; Park, G.T.; Rho, H.M. Activating transcription factor 2 (ATF2) down-regulates hepatitis $B$ virus $X$ promoter activity by the competition for the activating protein 1 binding site and the formation of the ATF2-Jun heterodimer. J. Biol. Chem. 1997, 272, 16934-16939. [CrossRef] [PubMed]

34. Lauer, U.; Weiss, L.; Lipp, M.; Hofschneider, P.H.; Kekule, A.S. The hepatitis B virus preS2/St transactivator utilizes AP-1 and other transcription factors for transactivation. Hepatology 1994, 19, 23-31. [CrossRef]

35. Ramji, D.P.; Foka, P. CCAAT/enhancer-binding proteins: Structure, function and regulation. Biochem. J. 2002, 365, 561-575. [CrossRef] [PubMed]

36. Kim, B.K.; Lim, S.O.; Park, Y.G. Requirement of the cyclic adenosine monophosphate response element-binding protein for hepatitis B virus replication. Hepatology 2008, 48, 361-373. [CrossRef] [PubMed]

37. Faktor, O.; Budlovsky, S.; Ben-Levy, R.; Shaul, Y. A single element within the hepatitis B virus enhancer binds multiple proteins and responds to multiple stimuli. J. Virol. 1990, 64, 1861-1863. [CrossRef]

38. Chen, M.; Hieng, S.; Qian, X.; Costa, R.; Ou, J.H. Regulation of hepatitis B virus ENI enhancer activity by hepatocyte-enriched transcription factor HNF3. Virology 1994, 205, 127-132. [CrossRef]

39. Yoneyama, M.; Koshiba, S.; Watabe, S.; Harada, T.; Kigawa, T.; Yokoyama, S.; RIKEN Structural Genomics/Proteomics Initiative (RSGI). Solution Structure of the Zinc Finger, C4-type domain of human COUP transcription Factor. Available online: https://www.rcsb.org/structure/2EBL (accessed on 30 March 2019).

40. Yang, Q.; Zhang, Q.; Zhang, X.; You, L.; Wang, W.; Liu, W.; Han, Y.; Ma, C.; Xu, W.; Chen, J.; et al. HoxA10 Facilitates SHP-1-Catalyzed Dephosphorylation of p38 MAPK/STAT3 To Repress Hepatitis B Virus Replication by a Feedback Regulatory Mechanism. J. Virol. 2019, 93. [CrossRef]

41. Lin, L.; Ghosh, S. A glycine-rich region in NF-kappaB p105 functions as a processing signal for the generation of the p50 subunit. Mol. Cell. Biol. 1996, 16, 2248-2254. [CrossRef]

42. Waris, G.; Huh, K.W.; Siddiqui, A. Mitochondrially associated hepatitis B virus X protein constitutively activates transcription factors STAT-3 and NF-kappa B via oxidative stress. Mol. Cell. Biol. 2001, 21, 7721-7730. [CrossRef]

43. Maity, S.N.; de Crombrugghe, B. Role of the CCAAT-binding protein CBF/NF-Y in transcription. Trends Biochem. Sci. 1998, 23, 174-178. [CrossRef]

44. Tokusumi, Y.; Zhou, S.; Takada, S. Nuclear respiratory factor 1 plays an essential role in transcriptional initiation from the hepatitis B virus x gene promoter. J. Virol. 2004, 78, 10856-10864. [CrossRef]

45. Hossain, M.B.; Ji, P.; Anish, R.; Jacobson, R.H.; Takada, S. Poly(ADP-ribose) Polymerase 1 Interacts with Nuclear Respiratory Factor 1 (NRF-1) and Plays a Role in NRF-1 Transcriptional Regulation. J. Biol. Chem. 2009, 284, 8621-8632. [CrossRef] [PubMed]

46. Zhou, D.X.; Yen, T.S. The ubiquitous transcription factor Oct-1 and the liver-specific factor HNF-1 are both required to activate transcription of a hepatitis B virus promoter. Mol. Cell. Biol. 1991, 11, 1353-1359. [CrossRef]

47. Qin, J.; Zhai, J.; Hong, R.; Shan, S.; Kong, Y.; Wen, Y.; Wang, Y.; Liu, J.; Xie, Y. Prospero-related homeobox protein (Prox1) inhibits hepatitis B virus replication through repressing multiple cis regulatory elements. J. Gen. Virol. 2009, 90, 1246-1255. [CrossRef] [PubMed]

48. Reith, W.; Ucla, C.; Barras, E.; Gaud, A.; Durand, B.; Herrero-Sanchez, C.; Kobr, M.; Mach, B. RFX1, a transactivator of hepatitis B virus enhancer I, belongs to a novel family of homodimeric and heterodimeric DNA-binding proteins. Mol. Cell. Biol. 1994, 14, 1230-1244. [CrossRef] 
49. Buckwold, V.E.; Chen, M.; Ou, J.H. Interaction of transcription factors RFX1 and MIBP1 with the gamma motif of the negative regulatory element of the hepatitis B virus core promoter. Virology 1997, 227, 515-518. [CrossRef]

50. Siegrist, C.A.; Durand, B.; Emery, P.; David, E.; Hearing, P.; Mach, B.; Reith, W. RFX1 is identical to enhancer factor $C$ and functions as a transactivator of the hepatitis B virus enhancer. Mol. Cell. Biol. 1993, 13, 6375-6384. [CrossRef]

51. Oropeza, C.E.; Li, L.; McLachlan, A. Differential inhibition of nuclear hormone receptor-dependent hepatitis B virus replication by the small heterodimer partner. J. Virol. 2008, 82, 3814-3821. [CrossRef]

52. Narayan, V.A.; Kriwacki, R.W.; Caradonna, J.P. Structures of zinc finger domains from transcription factor Sp1. Insights into sequence-specific protein-DNA recognition. J. Biol. Chem. 1997, 272, 7801-7809. [CrossRef]

53. Oka, S.; Shiraishi, Y.; Yoshida, T.; Ohkubo, T.; Sugiura, Y.; Kobayashi, Y. NMR structure of transcription factor Sp1 DNA binding domain. Biochemistry 2004, 43, 16027-16035. [CrossRef]

54. Wu, M.; Xu, Y.; Lin, S.; Zhang, X.; Xiang, L.; Yuan, Z. Hepatitis B virus polymerase inhibits the interferon-inducible MyD88 promoter by blocking nuclear translocation of Stat1. J. Gen. Virol. 2007, 88, 3260-3269. [CrossRef] [PubMed]

55. Belloni, L.; Allweiss, L.; Guerrieri, F.; Pediconi, N.; Volz, T.; Pollicino, T.; Petersen, J.; Raimondo, G.; Dandri, M.; Levrero, M. IFN-alpha inhibits HBV transcription and replication in cell culture and in humanized mice by targeting the epigenetic regulation of the nuclear cccDNA minichromosome. J. Clin. Investig. 2012, 122, 529-537. [CrossRef] [PubMed]

56. Yang, Y.; Zheng, B.; Han, Q.; Zhang, C.; Tian, Z.; Zhang, J. Targeting blockage of STAT3 inhibits hepatitis B virus-related hepatocellular carcinoma. Cancer Biol. Ther. 2016, 17, 449-456. [CrossRef] [PubMed]

57. Waris, G.; Siddiqui, A. Interaction between STAT-3 and HNF-3 leads to the activation of liver-specific hepatitis B virus enhancer 1 function. J. Virol. 2002, 76, 2721-2729. [CrossRef] [PubMed]

58. Bogomolski-Yahalom, V.; Klein, A.; Greenblat, I.; Haviv, Y.; Tur-Kaspa, R. The TATA-less promoter of hepatitis B virus $S$ gene contains a TBP binding site and an active initiator. Virus Res. 1997, 49, 1-7. [CrossRef]

59. Ghosh, M.; Elsby, L.M.; Mal, T.K.; Gooding, J.M.; Roberts, S.G.; Ikura, M. Probing Zn2+-binding effects on the zinc-ribbon domain of human general transcription factor TFIIB. Biochem. J. 2004, 378, 317-324. [CrossRef] [PubMed]

60. Lin, Y.; Nomura, T.; Cheong, J.; Dorjsuren, D.; Iida, K.; Murakami, S. Hepatitis B virus X protein is a transcriptional modulator that communicates with transcription factor IIB and the RNA polymerase II subunit 5. J. Biol. Chem. 1997, 272, 7132-7139. [CrossRef]

61. Lee, H.; Kim, H.T.; Yun, Y. Liver-specific enhancer II is the target for the p53-mediated inhibition of hepatitis B viral gene expression. J. Biol. Chem. 1998, 273, 19786-19791. [CrossRef]

62. Ori, A.; Zauberman, A.; Doitsh, G.; Paran, N.; Oren, M.; Shaul, Y. p53 binds and represses the HBV enhancer: An adjacent enhancer element can reverse the transcription effect of p53. EMBO J. 1998, 17, 544-553. [CrossRef]

63. Truant, R.; Antunovic, J.; Greenblatt, J.; Prives, C.; Cromlish, J.A. Direct interaction of the hepatitis B virus $\mathrm{HBx}$ protein with $\mathrm{p} 53$ leads to inhibition by HBx of p53 response element-directed transactivation. J. Virol. 1995, 69, 1851-1859. [CrossRef] [PubMed]

64. Nakanishi-Matsui, M.; Hayashi, Y.; Kitamura, Y.; Koike, K. Integrated hepatitis B virus DNA preserves the binding sequence of transcription factor Yin and Yang 1 at the virus-cell junction. J. Virol. 2000, 74, 5562-5568. [CrossRef] [PubMed]

65. He, Q.; Li, W.; Ren, J.; Huang, Y.; Huang, Y.; Hu, Q.; Chen, J.; Chen, W. ZEB2 inhibits HBV transcription and replication by targeting its core promoter. Oncotarget 2016, 7, 16003-16011. [CrossRef] [PubMed]

66. Mouzannar, K.; Fusil, F.; Lacombe, B.; Ollivier, A.; Menard, C.; Lotteau, V.; Cosset, F.L.; Ramiere, C.; Andre, P. Farnesoid $\mathrm{X}$ receptor-alpha is a proviral host factor for hepatitis B virus that is inhibited by ligands in vitro and in vivo. FASEB J. 2019, 33, 2472-2483. [CrossRef] [PubMed]

67. Ramiere, C.; Scholtes, C.; Diaz, O.; Icard, V.; Perrin-Cocon, L.; Trabaud, M.A.; Lotteau, V.; Andre, P. Transactivation of the hepatitis B virus core promoter by the nuclear receptor FXRalpha. J. Virol. 2008, 82, 10832-10840. [CrossRef]

68. Zhou, J.; Tan, T.; Tian, Y.; Zheng, B.; Ou, J.H.; Huang, E.J.; Yen, T.S. Kruppel-like factor 15 activates hepatitis B virus gene expression and replication. Hepatology 2011, 54, 109-121. [CrossRef] 
69. Xu, P.L.; Liu, Y.Q.; Shan, S.F.; Kong, Y.Y.; Zhou, Q.; Li, M.; Ding, J.P.; Xie, Y.H.; Wang, Y. Molecular mechanism for the potentiation of the transcriptional activity of human liver receptor homolog 1 by steroid receptor coactivator-1. Mol. Endocrinol. 2004, 18, 1887-1905. [CrossRef]

70. Cai, Y.N.; Zhou, Q.; Kong, Y.Y.; Li, M.; Viollet, B.; Xie, Y.H.; Wang, Y. LRH-1/hB1F and HNF1 synergistically up-regulate hepatitis B virus gene transcription and DNA replication. Cell Res. 2003, 13, 451-458. [CrossRef]

71. Li, J.; Xu, Z.; Zheng, Y.; Johnson, D.L.; Ou, J.H. Regulation of hepatocyte nuclear factor 1 activity by wild-type and mutant hepatitis B virus X proteins. J. Virol. 2002, 76, 5875-5881. [CrossRef]

72. Zheng, Y.; Li, J.; Ou, J.H. Regulation of hepatitis B virus core promoter by transcription factors HNF1 and HNF4 and the viral $X$ protein. J. Virol. 2004, 78, 6908-6914. [CrossRef]

73. Li, M.; Xie, Y.; Wu, X.; Kong, Y.; Wang, Y. HNF3 binds and activates the second enhancer, ENII, of hepatitis B virus. Virology 1995, 214, 371-378. [CrossRef] [PubMed]

74. Raney, A.K.; Zhang, P.; McLachlan, A. Regulation of transcription from the hepatitis B virus large surface antigen promoter by hepatocyte nuclear factor 3. J. Virol. 1995, 69, 3265-3272. [CrossRef] [PubMed]

75. Guo, W.; Chen, M.; Yen, T.S.; Ou, J.H. Hepatocyte-specific expression of the hepatitis B virus core promoter depends on both positive and negative regulation. Mol. Cell. Biol. 1993, 13, 443-448. [CrossRef] [PubMed]

76. Cho, E.Y.; Kim, H.J.; Park, C.; So, H.S.; Park, R.K.; Kim, H.C. Impact of Nucleotide Mutations at the HNF3and HNF4-Binding Sites in Enhancer 1 on Viral Replication in Patients with Chronic Hepatitis B Virus Infection. Gut Liver 2013, 7, 569-575. [CrossRef] [PubMed]

77. Long, Y.; Chen, E.; Liu, C.; Huang, F.; Zhou, T.; He, F.; Liu, L.; Liu, F.; Tang, H. The correlation of hepatocyte nuclear factor 4 alpha and 3 beta with hepatitis B virus replication in the liver of chronic hepatitis B patients. J. Viral Hepat. 2009, 16, 537-546. [CrossRef] [PubMed]

78. Hao, R.; He, J.; Liu, X.; Gao, G.; Liu, D.; Cui, L.; Yu, G.; Yu, W.; Chen, Y.; Guo, D. Inhibition of hepatitis B virus gene expression and replication by hepatocyte nuclear factor 6. J. Virol. 2015, 89, 4345-4355. [CrossRef]

79. Du, L.; Ma, Y.; Liu, M.; Yan, L.; Tang, H. Peroxisome Proliferators Activated Receptor (PPAR) agonists activate hepatitis B virus replication in vivo. Virol. J. 2017, 14, 96. [CrossRef]

80. Huan, B.; Kosovsky, M.J.; Siddiqui, A. Retinoid X receptor alpha transactivates the hepatitis B virus enhancer 1 element by forming a heterodimeric complex with the peroxisome proliferator-activated receptor. J. Virol. 1995, 69, 547-551. [CrossRef]

81. Tang, H.; Raney, A.K.; McLachlan, A. Replication of the wild type and a natural hepatitis B virus nucleocapsid promoter variant is differentially regulated by nuclear hormone receptors in cell culture. J. Virol. 2001, 75, 8937-8948. [CrossRef]

82. Xu, L.; Wu, Z.; Tan, S.; Wang, Z.; Lin, Q.; Li, X.; Song, X.; Liu, Y.; Song, Y.; Zhang, J.; et al. Tumor suppressor ZHX2 restricts hepatitis B virus replication via epigenetic and non-epigenetic manners. Antivir. Res. 2018, 153, 114-123. [CrossRef]

83. Romier, C.; Cocchiarella, F.; Mantovani, R.; Moras, D. The NF-YB/NF-YC structure gives insight into DNA binding and transcription regulation by CCAAT factor NF-Y. J. Biol. Chem. 2003, 278, 1336-1345. [CrossRef] [PubMed]

84. Nardini, M.; Gnesutta, N.; Donati, G.; Gatta, R.; Forni, C.; Fossati, A.; Vonrhein, C.; Moras, D.; Romier, C.; Bolognesi, M.; et al. Sequence-specific transcription factor NF-Y displays histone-like DNA binding and H2B-like ubiquitination. Cell 2013, 152, 132-143. [CrossRef] [PubMed]

85. Di Agostino, S.; Strano, S.; Emiliozzi, V.; Zerbini, V.; Mottolese, M.; Sacchi, A.; Blandino, G.; Piaggio, G. Gain of function of mutant p53: The mutant p53/NF-Y protein complex reveals an aberrant transcriptional mechanism of cell cycle regulation. Cancer cell 2006, 10, 191-202. [CrossRef] [PubMed]

86. Dolfini, D.; Gatta, R.; Mantovani, R. NF-Y and the transcriptional activation of CCAAT promoters. Crit. Rev. Biochem. Mol. Biol. 2012, 47, 29-49. [CrossRef] [PubMed]

87. Foo, N.C.; Yen, T.S. Activation of promoters for cellular lipogenic genes by hepatitis B virus large surface protein. Virology 2000, 269, 420-425. [CrossRef] [PubMed]

88. Taniguchi, K.; Karin, M. NF-kappaB, inflammation, immunity and cancer: Coming of age. Nat. Rev. Immunol 2018, 18, 309-324. [CrossRef] [PubMed]

89. Muller, C.W.; Rey, F.A.; Sodeoka, M.; Verdine, G.L.; Harrison, S.C. Structure of the NF-kappa B p50 homodimer bound to DNA. Nature 1995, 373, 311-317. [CrossRef] 
90. Berkowitz, B.; Huang, D.B.; Chen-Park, F.E.; Sigler, P.B.; Ghosh, G. The x-ray crystal structure of the NF-kappa B p50.p65 heterodimer bound to the interferon beta -kappa B site. J. Biol. Chem. 2002, 277, 24694-24700. [CrossRef]

91. Tak, P.P.; Firestein, G.S. NF-kappaB: A key role in inflammatory diseases. J. Clin. Investig. 2001, 107, 7-11. [CrossRef] [PubMed]

92. Wilson, R.; Warner, N.; Ryan, K.; Selleck, L.; Colledge, D.; Rodgers, S.; Li, K.; Revill, P.; Locarnini, S. The hepatitis B e antigen suppresses IL-1beta-mediated NF-kappaB activation in hepatocytes. J. Viral Hepat. 2011, 18, e499-e507. [CrossRef]

93. Hiscott, J.; Kwon, H.; Genin, P. Hostile takeovers: Viral appropriation of the NF-kappaB pathway. J. Clin. Investig. 2001, 107, 143-151. [CrossRef] [PubMed]

94. Pan, X.; Cao, H.; Lu, J.; Shu, X.; Xiong, X.; Hong, X.; Xu, Q.; Zhu, H.; Li, G.; Shen, G. Interleukin-32 expression induced by hepatitis B virus protein $X$ is mediated through activation of NF-kappaB. Mol. Immunol. 2011, 48, 1573-1577. [CrossRef] [PubMed]

95. Kaczynski, J.; Cook, T.; Urrutia, R. Sp1- and Kruppel-like transcription factors. Genome Biol. 2003, 4, 206. [CrossRef] [PubMed]

96. Chu, B.Y.; Tran, K.; Ku, T.K.; Crowe, D.L. Regulation of ERK1 gene expression by coactivator proteins. Biochem. J. 2005, 392, 589-599. [CrossRef] [PubMed]

97. Black, A.R.; Black, J.D.; Azizkhan-Clifford, J. Sp1 and kruppel-like factor family of transcription factors in cell growth regulation and cancer. J. Cell Physiol. 2001, 188, 143-160. [CrossRef] [PubMed]

98. Tan, N.Y.; Khachigian, L.M. Sp1 phosphorylation and its regulation of gene transcription. Mol. Cell. Biol. 2009, 29, 2483-2488. [CrossRef] [PubMed]

99. Vizcaino, C.; Mansilla, S.; Portugal, J. Sp1 transcription factor: A long-standing target in cancer chemotherapy. Pharmacol. Ther. 2015, 152, 111-124. [CrossRef]

100. Alfano, C.; Magrinelli, E.; Harb, K.; Studer, M. The nuclear receptors COUP-TF: A long-lasting experience in forebrain assembly. Cell Mol. Life Sci. 2014, 71, 43-62. [CrossRef]

101. Tsai, S.Y.; Tsai, M.J. Chick ovalbumin upstream promoter-transcription factors (COUP-TFs): Coming of age. Endocr Rev. 1997, 18, 229-240. [CrossRef]

102. Vivanco Ruiz, M.M.; Bugge, T.H.; Hirschmann, P.; Stunnenberg, H.G. Functional characterization of a natural retinoic acid responsive element. EMBO J. 1991, 10, 3829-3838. [CrossRef]

103. Kliewer, S.A.; Umesono, K.; Heyman, R.A.; Mangelsdorf, D.J.; Dyck, J.A.; Evans, R.M. Retinoid X receptor-COUP-TF interactions modulate retinoic acid signaling. Proc. Natl. Acad. Sci. USA 1992, 89, 1448-1452. [CrossRef]

104. Qiu, Y.; Tsai, S.Y.; Tsai, M.J. COUP-TF an orphan member of the steroid/thyroid hormone receptor superfamily. Trends Endocrinol Metab 1994, 5, 234-239. [CrossRef]

105. Pereira, F.A.; Tsai, M.J.; Tsai, S.Y. COUP-TF orphan nuclear receptors in development and differentiation. Cell Mol. Life Sci. 2000, 57, 1388-1398. [CrossRef]

106. Tripodi, M.; Filosa, A.; Armentano, M.; Studer, M. The COUP-TF nuclear receptors regulate cell migration in the mammalian basal forebrain. Development 2004, 131, 6119-6129. [CrossRef]

107. Garcia, A.D.; Ostapchuk, P.; Hearing, P. Functional interaction of nuclear factors EF-C, HNF-4, and RXR alpha with hepatitis B virus enhancer I. J. Virol. 1993, 67, 3940-3950. [CrossRef]

108. Li, Y.; Ito, M.; Sun, S.; Chida, T.; Nakashima, K.; Suzuki, T. LUC7L3/CROP inhibits replication of hepatitis B virus via suppressing enhancer II/basal core promoter activity. Sci. Rep. 2016, 6, 36741. [CrossRef]

109. Yu, X.; Mertz, J.E. Distinct modes of regulation of transcription of hepatitis B virus by the nuclear receptors HNF4alpha and COUP-TF1. J. Virol. 2003, 77, 2489-2499. [CrossRef]

110. Lekstrom-Himes, J.; Xanthopoulos, K.G. Biological role of the CCAAT/enhancer-binding protein family of transcription factors. J. Biol. Chem. 1998, 273, 28545-28548. [CrossRef]

111. Takiguchi, M. The C/EBP family of transcription factors in the liver and other organs. Int. J. Exp. Pathol. 1998, 79, 369-391. [CrossRef]

112. Wang, W.; Xia, X.; Mao, L.; Wang, S. The CCAAT/Enhancer-Binding Protein Family: Its Roles in MDSC Expansion and Function. Front. Immunol. 2019, 10, 1804. [CrossRef]

113. Choi, B.H.; Park, G.T.; Rho, H.M. Interaction of hepatitis B viral X protein and CCAAT/ enhancer-binding protein alpha synergistically activates the hepatitis B viral enhancer II/pregenomic promoter. J. Biol. Chem. 1999, 274, 2858-2865. [CrossRef] 
114. Lopez-Cabrera, M.; Letovsky, J.; Hu, K.Q.; Siddiqui, A. Multiple liver-specific factors bind to the hepatitis $\mathrm{B}$ virus core/pregenomic promoter: Trans-activation and repression by CCAAT/enhancer binding protein. Proc. Natl. Acad. Sci. USA 1990, 87, 5069-5073. [CrossRef]

115. Raney, A.K.; McLachlan, A. Characterization of the hepatitis B virus large surface antigen promoter Sp1 binding site. Virology 1995, 208, 399-404. [CrossRef]

116. Bock, C.T.; Kubicka, S.; Manns, M.P.; Trautwein, C. Two control elements in the hepatitis B virus S-promoter are important for full promoter activity mediated by CCAAT-binding factor. Hepatology 1999, 29, 1236-1247. [CrossRef]

117. Sarkar, N.; Chakravarty, R. Hepatitis B Virus Infection, MicroRNAs and Liver Disease. Int. J. Mol. Sci. 2015, 16, 17746-17762. [CrossRef]

118. Sarkar, N.; Panigrahi, R.; Pal, A.; Biswas, A.; Singh, S.P.; Kar, S.K.; Bandopadhyay, M.; Das, D.; Saha, D.; Kanda, T.; et al. Expression of microRNA-155 correlates positively with the expression of Toll-like receptor 7 and modulates hepatitis B virus via C/EBP-beta in hepatocytes. J. Viral Hepat. 2015, 22, 817-827. [CrossRef]

119. Sainsbury, S.; Niesser, J.; Cramer, P. Structure and function of the initially transcribing RNA polymerase II-TFIIB complex. Nature 2013, 493, 437-440. [CrossRef]

120. Haviv, I.; Shamay, M.; Doitsh, G.; Shaul, Y. Hepatitis B virus pX targets TFIIB in transcription coactivation. Mol. Cell. Biol. 1998, 18, 1562-1569. [CrossRef]

121. Zhou, Q.; Huang, F.; Chen, L.; Chen, E.; Bai, L.; Cheng, X.; He, M.; Tang, H. RPB5-Mediating Protein Suppresses Hepatitis B Virus (HBV) Transcription and Replication by Counteracting the Transcriptional Activation of Hepatitis B virus X Protein in HBV Replication Mouse Model. Jundishapur J. Microbiol. 2015, 8, e21936. [CrossRef]

122. Zhang, X.; Zhang, H.; Ye, L. Effects of hepatitis B virus X protein on the development of liver cancer. J. Lab. Clin. Med. 2006, 147, 58-66. [CrossRef]

123. Verschueren, K.; Remacle, J.E.; Collart, C.; Kraft, H.; Baker, B.S.; Tylzanowski, P.; Nelles, L.; Wuytens, G.; $\mathrm{Su}$, M.T.; Bodmer, R.; et al. SIP1, a novel zinc finger/homeodomain repressor, interacts with Smad proteins and binds to 5'-CACCT sequences in candidate target genes. J. Biol. Chem. 1999, 274, 20489-20498. [CrossRef] [PubMed]

124. Postigo, A.A.; Depp, J.L.; Taylor, J.J.; Kroll, K.L. Regulation of Smad signaling through a differential recruitment of coactivators and corepressors by ZEB proteins. EMBO J. 2003, 22, 2453-2462. [CrossRef] [PubMed]

125. Van de Putte, T.; Maruhashi, M.; Francis, A.; Nelles, L.; Kondoh, H.; Huylebroeck, D.; Higashi, Y. Mice lacking ZFHX1B, the gene that codes for Smad-interacting protein-1, reveal a role for multiple neural crest cell defects in the etiology of Hirschsprung disease-mental retardation syndrome. Am. J. Hum. Genet. 2003, 72, 465-470. [CrossRef] [PubMed]

126. Van de Putte, T.; Francis, A.; Nelles, L.; van Grunsven, L.A.; Huylebroeck, D. Neural crest-specific removal of $\mathrm{Zfhx} 1 \mathrm{~b}$ in mouse leads to a wide range of neurocristopathies reminiscent of Mowat-Wilson syndrome. Hum. Mol. Genet. 2007, 16, 1423-1436. [CrossRef] [PubMed]

127. Epifanova, E.; Babaev, A.; Newman, A.G.; Tarabykin, V. Role of Zeb2/Sip1 in neuronal development. Brain Res. 2019, 1705, 24-31. [CrossRef]

128. Remacle, J.E.; Kraft, H.; Lerchner, W.; Wuytens, G.; Collart, C.; Verschueren, K.; Smith, J.C.; Huylebroeck, D. New mode of DNA binding of multi-zinc finger transcription factors: DeltaEF1 family members bind with two hands to two target sites. EMBO J. 1999, 18, 5073-5084. [CrossRef]

129. Long, J.; Zuo, D.; Park, M. Pc2-mediated sumoylation of Smad-interacting protein 1 attenuates transcriptional repression of E-cadherin. J. Biol. Chem. 2005, 280, 35477-35489. [CrossRef]

130. Kamada, R.; Toguchi, Y.; Nomura, T.; Imagawa, T.; Sakaguchi, K. Tetramer formation of tumor suppressor protein p53: Structure, function, and applications. Biopolymers 2016, 106, 598-612. [CrossRef]

131. Vieler, M.; Sanyal, S. p53 Isoforms and Their Implications in Cancer. Cancers 2018, 10, 288. [CrossRef]

132. Kearns, S.; Lurz, R.; Orlova, E.V.; Okorokov, A.L. Two p53 tetramers bind one consensus DNA response element. Nucleic Acids Res. 2016, 44, 6185-6199. [CrossRef]

133. Kitayner, M.; Rozenberg, H.; Kessler, N.; Rabinovich, D.; Shaulov, L.; Haran, T.E.; Shakked, Z. Structural basis of DNA recognition by p53 tetramers. Mol. Cell 2006, 22, 741-753. [CrossRef] 
134. Kim, H.; Lee, Y.H.; Won, J.; Yun, Y. Through induction of juxtaposition and tyrosine kinase activity of Jak1, X-gene product of hepatitis B virus stimulates Ras and the transcriptional activation through AP-1, NF-kappaB, and SRE enhancers. Biochem. Biophys. Res. Commun. 2001, 286, 886-894. [CrossRef]

135. Chan, C.; Thurnherr, T.; Wang, J.; Gallart-Palau, X.; Sze, S.K.; Rozen, S.; Lee, C.G. Global re-wiring of p53 transcription regulation by the hepatitis B virus X protein. Mol. Oncol. 2016, 10, 1183-1195. [CrossRef]

136. Katan-Khaykovich, Y.; Shaul, Y. Nuclear import and DNA-binding activity of RFX1. Evidence for an autoinhibitory mechanism. Eur. J. Biochem. 2001, 268, 3108-3116. [CrossRef]

137. Gajiwala, K.S.; Chen, H.; Cornille, F.; Roques, B.P.; Reith, W.; Mach, B.; Burley, S.K. Structure of the winged-helix protein hRFX1 reveals a new mode of DNA binding. Nature 2000, 403, 916-921. [CrossRef]

138. Julien, L.; Chassagne, J.; Peccate, C.; Lorain, S.; Pietri-Rouxel, F.; Danos, O.; Benkhelifa-Ziyyat, S. RFX1 and RFX3 Transcription Factors Interact with the D Sequence of Adeno-Associated Virus Inverted Terminal Repeat and Regulate AAV Transduction. Sci. Rep. 2018, 8, 210. [CrossRef]

139. Zanatta, A.; Rocha, A.M.; Carvalho, F.M.; Pereira, R.M.; Taylor, H.S.; Motta, E.L.; Baracat, E.C.; Serafini, P.C. The role of the Hoxa10/HOXA10 gene in the etiology of endometriosis and its related infertility: A review. J. Assist. Reprod Genet. 2010, 27, 701-710. [CrossRef]

140. Du, H.; Taylor, H.S. The Role of Hox Genes in Female Reproductive Tract Development, Adult Function, and Fertility. Cold Spring Harbor. Perspect. Med. 2015, 6, a023002. [CrossRef] [PubMed]

141. Ji, F.; Yang, X.; He, Y.; Wang, H.; Aili, A.; Ding, Y. Aberrant endometrial DNA methylome of homeobox A10 and catechol-O-methyltransferase in endometriosis. J. Assist. Reprod. Genet. 2017, 34, 409-415. [CrossRef]

142. Benson, G.V.; Nguyen, T.H.; Maas, R.L. The expression pattern of the murine Hoxa-10 gene and the sequence recognition of its homeodomain reveal specific properties of Abdominal B-like genes. Mol. Cell. Biol. 1995, 15, 1591-1601. [CrossRef]

143. Suzuki, N.; Peter, W.; Ciesiolka, T.; Gruss, P.; Scholer, H.R. Mouse Oct-1 contains a composite homeodomain of human Oct-1 and Oct-2. Nucleic Acids Res. 1993, 21, 245-252. [CrossRef] [PubMed]

144. Kemler, I.; Schaffner, W. Octamer transcription factors and the cell type-specificity of immunoglobulin gene expression. FASEB J. 1990, 4, 1444-1449. [CrossRef] [PubMed]

145. Herr, W.; Cleary, M.A. The POU domain: Versatility in transcriptional regulation by a flexible two-in-one DNA-binding domain. Genes Dev. 1995, 9, 1679-1693. [CrossRef]

146. Hwang, S.S.; Kim, L.K.; Lee, G.R.; Flavell, R.A. Role of OCT-1 and partner proteins in T cell differentiation. Biochim. Biophys. Acta 2016, 1859, 825-831. [CrossRef]

147. Tantin, D.; Schild-Poulter, C.; Wang, V.; Hache, R.J.; Sharp, P.A. The octamer binding transcription factor Oct-1 is a stress sensor. Cancer Res. 2005, 65, 10750-10758. [CrossRef]

148. Vazquez-Arreguin, K.; Tantin, D. The Oct1 transcription factor and epithelial malignancies: Old protein learns new tricks. Biochim. Biophys. Acta 2016, 1859, 792-804. [CrossRef]

149. Antunovic, J.; Lemieux, N.; Cromlish, J.A. The 17 kDa HBx protein encoded by hepatitis B virus interacts with the activation domains of Oct-1, and functions as a coactivator in the activation and repression of a human U6 promoter. Cell Mol. Biol Res. 1993, 39, 463-482.

150. Scarpulla, R.C. Nuclear control of respiratory gene expression in mammalian cells. J. Cell Biochem. 2006, 97, 673-683. [CrossRef]

151. Niu, N.; Li, Z.; Zhu, M.; Sun, H.; Yang, J.; Xu, S.; Zhao, W.; Song, R. Effects of nuclear respiratory factor1 on apoptosis and mitochondrial dysfunction induced by cobalt chloride in H9C2 cells. Mol. Med. Rep. 2019, 19, 2153-2163. [CrossRef]

152. Morrish, F.; Giedt, C.; Hockenbery, D. c-MYC apoptotic function is mediated by NRF-1 target genes. Genes Dev. 2003, 17, 240-255. [CrossRef]

153. Virbasius, C.A.; Virbasius, J.V.; Scarpulla, R.C. NRF-1, an activator involved in nuclear-mitochondrial interactions, utilizes a new DNA-binding domain conserved in a family of developmental regulators. Genes Dev. 1993, 7, 2431-2445. [CrossRef]

154. Gugneja, S.; Scarpulla, R.C. Serine phosphorylation within a concise amino-terminal domain in nuclear respiratory factor 1 enhances DNA binding. J. Biol. Chem. 1997, 272, 18732-18739. [CrossRef]

155. Meissl, K.; Macho-Maschler, S.; Muller, M.; Strobl, B. The good and the bad faces of STAT1 in solid tumours. Cytokine 2017, 89, 12-20. [CrossRef]

156. Mogensen, T.H. IRF and STAT Transcription Factors - From Basic Biology to Roles in Infection, Protective Immunity, and Primary Immunodeficiencies. Front. Immunol. 2018, 9, 3047. [CrossRef] 
157. Roy, B.; Zuo, Z.; Stormo, G.D. Quantitative specificity of STAT1 and several variants. Nucleic Acids Res. 2017, 45, 8199-8207. [CrossRef]

158. Ehret, G.B.; Reichenbach, P.; Schindler, U.; Horvath, C.M.; Fritz, S.; Nabholz, M.; Bucher, P. DNA binding specificity of different STAT proteins. Comparison of in vitro specificity with natural target sites. J. Biol. Chem. 2001, 276, 6675-6688. [CrossRef]

159. Jiang, J.; Tang, H. Mechanism of inhibiting type I interferon induction by hepatitis B virus $X$ protein. Protein Cell 2010, 1, 1106-1117. [CrossRef]

160. Jiang, H.; Yu, J.; Guo, H.; Song, H.; Chen, S. Upregulation of survivin by leptin/STAT3 signaling in MCF-7 cells. Biochem. Biophys. Res. Commun. 2008, 368, 1-5. [CrossRef]

161. Tsai, Y.T.; Su, Y.H.; Fang, S.S.; Huang, T.N.; Qiu, Y.; Jou, Y.S.; Shih, H.M.; Kung, H.J.; Chen, R.H. Etk, a Btk family tyrosine kinase, mediates cellular transformation by linking Src to STAT3 activation. Mol. Cell. Biol. 2000, 20, 2043-2054. [CrossRef]

162. Ma, L.; Huang, C.; Wang, X.J.; Xin, D.E.; Wang, L.S.; Zou, Q.C.; Zhang, Y.S.; Tan, M.D.; Wang, Y.M.; Zhao, T.C.; et al. Lysyl Oxidase 3 Is a Dual-Specificity Enzyme Involved in STAT3 Deacetylation and Deacetylimination Modulation. Mol. Cell 2017, 65, 296-309. [CrossRef]

163. Wang, R.; Cherukuri, P.; Luo, J. Activation of Stat3 sequence-specific DNA binding and transcription by p300/CREB-binding protein-mediated acetylation. J. Biol. Chem. 2005, 280, 11528-11534. [CrossRef] [PubMed]

164. Garces de Los Fayos Alonso, I.; Liang, H.C.; Turner, S.D.; Lagger, S.; Merkel, O.; Kenner, L. The Role of Activator Protein-1 (AP-1) Family Members in CD30-Positive Lymphomas. Cancers 2018, 10, 93. [CrossRef] [PubMed]

165. Papoudou-Bai, A.; Hatzimichael, E.; Barbouti, A.; Kanavaros, P. Expression patterns of the activator protein-1 (AP-1) family members in lymphoid neoplasms. Clin. Exp. Med. 2017, 17, 291-304. [CrossRef] [PubMed]

166. Trop-Steinberg, S.; Azar, Y. AP-1 Expression and its Clinical Relevance in Immune Disorders and Cancer. Am. J. Med. Sci. 2017, 353, 474-483. [CrossRef]

167. Angel, P.; Imagawa, M.; Chiu, R.; Stein, B.; Imbra, R.J.; Rahmsdorf, H.J.; Jonat, C.; Herrlich, P.; Karin, M. Phorbol ester-inducible genes contain a common cis element recognized by a TPA-modulated trans-acting factor. Cell 1987, 49, 729-739. [CrossRef]

168. Kang, L.J.; Choi, Y.J.; Lee, S.G. Stimulation of TRAF6/TAK1 degradation and inhibition of JNK/AP-1 signalling by ginsenoside Rg3 attenuates hepatitis B virus replication. Int. J. Biochem. Cell Biol. 2013, 45, 2612-2621. [CrossRef]

169. Tanaka, Y.; Kanai, F.; Ichimura, T.; Tateishi, K.; Asaoka, Y.; Guleng, B.; Jazag, A.; Ohta, M.; Imamura, J.; Ikenoue, T.; et al. The hepatitis B virus X protein enhances AP-1 activation through interaction with Jab1. Oncogene 2006, 25, 633-642. [CrossRef]

170. Kim, H.S.; Ryu, C.J.; Hong, H.J. Hepatitis B virus preS1 functions as a transcriptional activation domain. J. Gen. Virol 1997, 78 Pt 5, 1083-1086. [CrossRef]

171. Elsir, T.; Smits, A.; Lindstrom, M.S.; Nister, M. Transcription factor PROX1: Its role in development and cancer. Cancer Metastasis Rev. 2012, 31, 793-805. [CrossRef]

172. Takeda, Y.; Jetten, A.M. Prospero-related homeobox 1 (Prox1) functions as a novel modulator of retinoic acid-related orphan receptors alpha- and gamma-mediated transactivation. Nucleic Acids Res. 2013, 41, 6992-7008. [CrossRef]

173. Stergiopoulos, A.; Elkouris, M.; Politis, P.K. Prospero-related homeobox 1 (Prox1) at the crossroads of diverse pathways during adult neural fate specification. Front. Cell Neurosci. 2014, 8, 454. [CrossRef] [PubMed]

174. Audette, D.S.; Anand, D.; So, T.; Rubenstein, T.B.; Lachke, S.A.; Lovicu, F.J.; Duncan, M.K. Prox1 and fibroblast growth factor receptors form a novel regulatory loop controlling lens fiber differentiation and gene expression. Development 2016, 143, 318-328. [CrossRef] [PubMed]

175. Qin, J.; Gao, D.M.; Jiang, Q.F.; Zhou, Q.; Kong, Y.Y.; Wang, Y.; Xie, Y.H. Prospero-related homeobox (Prox1) is a corepressor of human liver receptor homolog-1 and suppresses the transcription of the cholesterol 7-alpha-hydroxylase gene. Mol. Endocrinol. 2004, 18, 2424-2439. [CrossRef] [PubMed]

176. Hoffman, A.; Sinn, E.; Yamamoto, T.; Wang, J.; Roy, A.; Horikoshi, M.; Roeder, R.G. Highly conserved core domain and unique $\mathrm{N}$ terminus with presumptive regulatory motifs in a human TATA factor (TFIID). Nature 1990, 346, 387-390. [CrossRef] [PubMed] 
177. Nikolov, D.B.; Chen, H.; Halay, E.D.; Hoffman, A.; Roeder, R.G.; Burley, S.K. Crystal structure of a human TATA box-binding protein/TATA element complex. Proc. Natl. Acad. Sci. USA 1996, 93, 4862-4867. [CrossRef]

178. Nikolov, D.B.; Hu, S.H.; Lin, J.; Gasch, A.; Hoffmann, A.; Horikoshi, M.; Chua, N.H.; Roeder, R.G.; Burley, S.K. Crystal structure of TFIID TATA-box binding protein. Nature 1992, 360, 40-46. [CrossRef]

179. Qadri, I.; Maguire, H.F.; Siddiqui, A. Hepatitis B virus transactivator protein X interacts with the TATA-binding protein. Proc. Natl. Acad. Sci. USA 1995, 92, 1003-1007. [CrossRef]

180. Wang, C.C.; Chen, J.J.; Yang, P.C. Multifunctional transcription factor YY1: A therapeutic target in human cancer? Expert Opin. Ther. Targets 2006, 10, 253-266. [CrossRef]

181. Galloway, N.R.; Ball, K.F.; Stiff, T.; Wall, N.R. Yin Yang 1 (YY1): Regulation of Survivin and Its Role In Invasion and Metastasis. Crit. Rev. Oncog. 2017, 22, 23-36. [CrossRef]

182. Shi, Y.; Lee, J.S.; Galvin, K.M. Everything you have ever wanted to know about Yin Yang 1. Biochim. Biophys. Acta 1997, 1332, F49-F66. [CrossRef]

183. Zhang, X.; Hou, J.; Lu, M. Regulation of hepatitis B virus replication by epigenetic mechanisms and microRNAs. Front. Genet. 2013, 4, 202. [CrossRef] [PubMed]

184. Hayashi, Y.; Kitamura, Y.; Nakanishi, M.; Koike, K. The binding site of transcription factor YY1 is required for intramolecular recombination between terminally repeated sequences of linear replicative hepatitis B virus DNA. J. Virol. 2000, 74, 9471-9478. [CrossRef] [PubMed]

185. Shang, J.; Zheng, Y.; Guo, X.; Mo, J.; Xie, X.; Xiong, Y.; Liu, Y.; Wu, K.; Wu, J. Hepatitis B virus replication and sex-determining region $\mathrm{Y}$ box 4 production are tightly controlled by a novel positive feedback mechanism. Sci. Rep. 2015, 5, 10066. [CrossRef] [PubMed]

186. Yu, T.; Li, Y.J.; Bian, A.H.; Zuo, H.B.; Zhu, T.W.; Ji, S.X.; Kong, F.; Yin, D.Q.; Wang, C.B.; Wang, Z.F.; et al. The regulatory role of activating transcription factor 2 in inflammation. Mediators Inflamm. 2014, 2014, 950472. [CrossRef]

187. Kawasaki, H.; Schiltz, L.; Chiu, R.; Itakura, K.; Taira, K.; Nakatani, Y.; Yokoyama, K.K. ATF-2 has intrinsic histone acetyltransferase activity which is modulated by phosphorylation. Nature 2000, 405, 195-200. [CrossRef]

188. Bhoumik, A.; Takahashi, S.; Breitweiser, W.; Shiloh, Y.; Jones, N.; Ronai, Z. ATM-dependent phosphorylation of ATF2 is required for the DNA damage response. Mol. Cell 2005, 18, 577-587. [CrossRef]

189. Nagadoi, A.; Nakazawa, K.; Uda, H.; Okuno, K.; Maekawa, T.; Ishii, S.; Nishimura, Y. Solution structure of the transactivation domain of ATF-2 comprising a zinc finger-like subdomain and a flexible subdomain. J. Mol. Biol. 1999, 287, 593-607. [CrossRef]

190. Newell, C.L.; Deisseroth, A.B.; Lopez-Berestein, G. Interaction of nuclear proteins with an AP-1/CRE-like promoter sequence in the human TNF-alpha gene. J. Leukoc Biol 1994, 56, 27-35. [CrossRef]

191. Alberini, C.M. Transcription factors in long-term memory and synaptic plasticity. Physiol. Rev. 2009, 89, 121-145. [CrossRef]

192. Sakamoto, K.M.; Frank, D.A. CREB in the pathophysiology of cancer: Implications for targeting transcription factors for cancer therapy. Clin. Cancer Res. 2009, 15, 2583-2587. [CrossRef]

193. Herzig, S.; Long, F.; Jhala, U.S.; Hedrick, S.; Quinn, R.; Bauer, A.; Rudolph, D.; Schutz, G.; Yoon, C.; Puigserver, P.; et al. CREB regulates hepatic gluconeogenesis through the coactivator PGC-1. Nature 2001, 413, 179-183. [CrossRef] [PubMed]

194. Adya, N.; Zhao, L.J.; Huang, W.; Boros, I.; Giam, C.Z. Expansion of CREB's DNA recognition specificity by Tax results from interaction with Ala-Ala-Arg at positions 282-284 near the conserved DNA-binding domain of CREB. Proc. Natl. Acad. Sci. USA 1994, 91, 5642-5646. [CrossRef] [PubMed]

195. Tang, H.M.; Gao, W.W.; Chan, C.P.; Cheng, Y.; Chaudhary, V.; Deng, J.J.; Yuen, K.S.; Wong, C.M.; Ng, I.O.; Kok, K.H.; et al. Requirement of CRTC1 coactivator for hepatitis B virus transcription. Nucleic Acids Res. 2014, 42, 12455-12468. [CrossRef]

196. Yuk, J.M.; Jin, H.S.; Jo, E.K. Small Heterodimer Partner and Innate Immune Regulation. Endocrinol. Metab. 2016, 31, 17-24. [CrossRef] [PubMed]

197. Song, G.; Wang, L. Transcriptional mechanism for the paired miR-433 and miR-127 genes by nuclear receptors SHP and ERRgamma. Nucleic Acids Res. 2008, 36, 5727-5735. [CrossRef]

198. Zhang, Y.; Hagedorn, C.H.; Wang, L. Role of nuclear receptor SHP in metabolism and cancer. Biochim. Biophys. Acta 2011, 1812, 893-908. [CrossRef] 
199. Miao, J.; Xiao, Z.; Kanamaluru, D.; Min, G.; Yau, P.M.; Veenstra, T.D.; Ellis, E.; Strom, S.; Suino-Powell, K.; $\mathrm{Xu}$, H.E.; et al. Bile acid signaling pathways increase stability of Small Heterodimer Partner (SHP) by inhibiting ubiquitin-proteasomal degradation. Genes Dev. 2009, 23, 986-996. [CrossRef]

200. Reese, V.C.; Moore, D.D.; McLachlan, A. Limited effects of bile acids and small heterodimer partner on hepatitis B virus biosynthesis in vivo. J. Virol. 2012, 86, 2760-2768. [CrossRef]

201. Chi, Y.I.; Frantz, J.D.; Oh, B.C.; Hansen, L.; Dhe-Paganon, S.; Shoelson, S.E. Diabetes mutations delineate an atypical POU domain in HNF-1alpha. Mol. Cell 2002, 10, 1129-1137. [CrossRef]

202. Chandra, V.; Huang, P.; Potluri, N.; Wu, D.; Kim, Y.; Rastinejad, F. Multidomain integration in the structure of the HNF-4alpha nuclear receptor complex. Nature 2013, 495, 394-398. [CrossRef]

203. Van Dijk, M.; Bonvin, A.M. 3D-DART: A DNA structure modelling server. Nucleic Acids Res. 2009, 37, W235-W239. [CrossRef] [PubMed]

204. Iyaguchi, D.; Yao, M.; Watanabe, N.; Nishihira, J.; Tanaka, I. DNA recognition mechanism of the ONECUT homeodomain of transcription factor HNF-6. Structure 2007, 15, 75-83. [CrossRef] [PubMed]

205. Bird, L.E.; Ren, J.; Nettleship, J.E.; Folkers, G.E.; Owens, R.J.; Stammers, D.K. Novel structural features in two ZHX homeodomains derived from a systematic study of single and multiple domains. BMC Struct. Biol. 2010, 10, 13. [CrossRef] [PubMed]

206. Li, J.; Zong, L.; Sureau, C.; Barker, L.; Wands, J.R.; Tong, S. Unusual Features of Sodium Taurocholate Cotransporting Polypeptide as a Hepatitis B Virus Receptor. J. Virol. 2016, 90, 8302-8313. [CrossRef] [PubMed]

207. Ni, Y.; Lempp, F.A.; Mehrle, S.; Nkongolo, S.; Kaufman, C.; Falth, M.; Stindt, J.; Koniger, C.; Nassal, M.; Kubitz, R.; et al. Hepatitis B and D viruses exploit sodium taurocholate co-transporting polypeptide for species-specific entry into hepatocytes. Gastroenterology 2014, 146, 1070-1083. [CrossRef] [PubMed]

208. Sun, Y.; Qi, Y.; Peng, B.; Li, W. NTCP-Reconstituted In Vitro HBV Infection System. Methods Mol. Biol. 2017, 1540, 1-14. [CrossRef] [PubMed]

209. Yu, Y.; Li, S.; Liang, W. Bona fide receptor for hepatitis B and D viral infections: Mechanism, research models and molecular drug targets. Emerg. Microbes Infect. 2018, 7, 134. [CrossRef]

210. Singh, V.; Singla, S.K.; Jha, V.; Puri, V.; Puri, S. Hepatocyte nuclear factor-1beta: A regulator of kidney development and cystogenesis. Indian J. Nephrol. 2015, 25, 70-76. [CrossRef]

211. Lau, H.H.; Ng, N.H.J.; Loo, L.S.W.; Jasmen, J.B.; Teo, A.K.K. The molecular functions of hepatocyte nuclear factors - In and beyond the liver. J. Hepatol. 2018, 68, 1033-1048. [CrossRef]

212. De Simone, V.; De Magistris, L.; Lazzaro, D.; Gerstner, J.; Monaci, P.; Nicosia, A.; Cortese, R. LFB3, a heterodimer-forming homeoprotein of the LFB1 family, is expressed in specialized epithelia. EMBO J. 1991, 10, 1435-1443. [CrossRef]

213. Rey-Campos, J.; Chouard, T.; Yaniv, M.; Cereghini, S. vHNF1 is a homeoprotein that activates transcription and forms heterodimers with HNF1. EMBO J. 1991, 10, 1445-1457. [CrossRef]

214. Odom, D.T.; Zizlsperger, N.; Gordon, D.B.; Bell, G.W.; Rinaldi, N.J.; Murray, H.L.; Volkert, T.L.; Schreiber, J.; Rolfe, P.A.; Gifford, D.K.; et al. Control of pancreas and liver gene expression by HNF transcription factors. Science 2004, 303, 1378-1381. [CrossRef] [PubMed]

215. Servitja, J.M.; Pignatelli, M.; Maestro, M.A.; Cardalda, C.; Boj, S.F.; Lozano, J.; Blanco, E.; Lafuente, A.; McCarthy, M.I.; Sumoy, L.; et al. Hnf1alpha (MODY3) controls tissue-specific transcriptional programs and exerts opposed effects on cell growth in pancreatic islets and liver. Mol. Cell. Biol. 2009, 29, 2945-2959. [CrossRef] [PubMed]

216. Von Wnuck Lipinski, K.; Sattler, K.; Peters, S.; Weske, S.; Keul, P.; Klump, H.; Heusch, G.; Gothert, J.R.; Levkau, B. Hepatocyte Nuclear Factor 1A Is a Cell-Intrinsic Transcription Factor Required for B Cell Differentiation and Development in Mice. J. Immunol. 2016, 196, 1655-1665. [CrossRef] [PubMed]

217. Wang, W.X.; Li, M.; Wu, X.; Wang, Y.; Li, Z.P. HNF1 is critical for the liver-specific function of HBV enhancer II. Res. Virol. 1998, 149, 99-108. [CrossRef]

218. Bar-Yishay, I.; Shaul, Y.; Shlomai, A. Hepatocyte metabolic signalling pathways and regulation of hepatitis B virus expression. Liver Int. 2011, 31, 282-290. [CrossRef]

219. Lin, J.; Gu, C.; Shen, Z.; Liu, Y.; Wang, W.; Tao, S.; Cui, X.; Liu, J.; Xie, Y. Hepatocyte nuclear factor 1alpha downregulates HBV gene expression and replication by activating the NF-kappaB signaling pathway. PLoS ONE 2017, 12, e0174017. [CrossRef] 
220. Li, J.; Dantas Machado, A.C.; Guo, M.; Sagendorf, J.M.; Zhou, Z.; Jiang, L.; Chen, X.; Wu, D.; Qu, L.; Chen, Z.; et al. Structure of the Forkhead Domain of FOXA2 Bound to a Complete DNA Consensus Site. Biochemistry 2017, 56, 3745-3753. [CrossRef]

221. Sund, N.J.; Ang, S.L.; Sackett, S.D.; Shen, W.; Daigle, N.; Magnuson, M.A.; Kaestner, K.H. Hepatocyte nuclear factor 3beta (Foxa2) is dispensable for maintaining the differentiated state of the adult hepatocyte. Mol. Cell. Biol. 2000, 20, 5175-5183. [CrossRef]

222. Sund, N.J.; Vatamaniuk, M.Z.; Casey, M.; Ang, S.L.; Magnuson, M.A.; Stoffers, D.A.; Matschinsky, F.M.; Kaestner, K.H. Tissue-specific deletion of Foxa2 in pancreatic beta cells results in hyperinsulinemic hypoglycemia. Genes Dev. 2001, 15, 1706-1715. [CrossRef]

223. Wolfrum, C.; Stoffel, M. Coactivation of Foxa2 through Pgc-1beta promotes liver fatty acid oxidation and triglyceride/VLDL secretion. Cell Metab. 2006, 3, 99-110. [CrossRef] [PubMed]

224. Ori, A.; Shaul, Y. Hepatitis B virus enhancer binds and is activated by the Hepatocyte nuclear factor 3. Virology 1995, 207, 98-106. [CrossRef] [PubMed]

225. Tang, H.; McLachlan, A. Mechanisms of inhibition of nuclear hormone receptor-dependent hepatitis B virus replication by hepatocyte nuclear factor 3beta. J. Virol. 2002, 76, 8572-8581. [CrossRef] [PubMed]

226. Cirillo, L.A.; Lin, F.R.; Cuesta, I.; Friedman, D.; Jarnik, M.; Zaret, K.S. Opening of compacted chromatin by early developmental transcription factors HNF3 (FoxA) and GATA-4. Mol. Cell 2002, 9, 279-289. [CrossRef]

227. Gallastegui, N.; Mackinnon, J.A.; Fletterick, R.J.; Estebanez-Perpina, E. Advances in our structural understanding of orphan nuclear receptors. Trends Biochem. Sci. 2015, 40, 25-35. [CrossRef] [PubMed]

228. Drewes, T.; Senkel, S.; Holewa, B.; Ryffel, G.U. Human hepatocyte nuclear factor 4 isoforms are encoded by distinct and differentially expressed genes. Mol. Cell. Biol. 1996, 16, 925-931. [CrossRef]

229. Babeu, J.P.; Boudreau, F. Hepatocyte nuclear factor 4-alpha involvement in liver and intestinal inflammatory networks. World J. Gastroenterol. 2014, 20, 22-30. [CrossRef]

230. Hwang-Verslues, W.W.; Sladek, F.M. HNF4alpha-Role in drug metabolism and potential drug target? Curr. Opin. Pharmacol. 2010, 10, 698-705. [CrossRef]

231. Chen, L.; Vasoya, R.P.; Toke, N.H.; Parthasarathy, A.; Luo, S.; Chiles, E.; Flores, J.; Gao, N.; Bonder, E.M.; $\mathrm{Su}, \mathrm{X}$.; et al. HNF4 Regulates Fatty Acid Oxidation and is Required for Renewal of Intestinal Stem Cells in Mice. Gastroenterology 2019. [CrossRef]

232. Garrison, W.D.; Battle, M.A.; Yang, C.; Kaestner, K.H.; Sladek, F.M.; Duncan, S.A. Hepatocyte nuclear factor 4alpha is essential for embryonic development of the mouse colon. Gastroenterology 2006, 130, 1207-1220. [CrossRef]

233. Xia, Y.; Cheng, X.; Li, Y.; Valdez, K.; Chen, W.; Liang, T.J. Hepatitis B Virus Deregulates the Cell Cycle To Promote Viral Replication and a Premalignant Phenotype. J. Virol. 2018, 92. [CrossRef] [PubMed]

234. He, F.; Chen, E.Q.; Liu, L.; Zhou, T.Y.; Liu, C.; Cheng, X.; Liu, F.J.; Tang, H. Inhibition of hepatitis B Virus replication by hepatocyte nuclear factor 4-alpha specific short hairpin RNA. Liver Int. 2012, 32, 742-751. [CrossRef] [PubMed]

235. Wang, S.H.; Yeh, S.H.; Lin, W.H.; Yeh, K.H.; Yuan, Q.; Xia, N.S.; Chen, D.S.; Chen, P.J. Estrogen receptor alpha represses transcription of HBV genes via interaction with hepatocyte nuclear factor 4alpha. Gastroenterology 2012, 142, 989-998.e4. [CrossRef] [PubMed]

236. Sheng, W.; Yan, H.; Rausa, F.M., 3rd; Costa, R.H.; Liao, X. Structure of the hepatocyte nuclear factor 6alpha and its interaction with DNA. J. Biol. Chem. 2004, 279, 33928-33936. [CrossRef]

237. Iyaguchi, D.; Yao, M.; Watanabe, N.; Nishihira, J.; Tanaka, I. Crystallization and preliminary X-ray studies of the DNA-binding domain of hepatocyte nuclear factor-6alpha complexed with DNA. Protein Pept Lett. 2006, 13, 531-533. [CrossRef]

238. Zhang, H.; Ables, E.T.; Pope, C.F.; Washington, M.K.; Hipkens, S.; Means, A.L.; Path, G.; Seufert, J.; Costa, R.H.; Leiter, A.B.; et al. Multiple, temporal-specific roles for HNF6 in pancreatic endocrine and ductal differentiation. Mech. Dev. 2009, 126, 958-973. [CrossRef]

239. Zhang, Y.; Fang, B.; Damle, M.; Guan, D.; Li, Z.; Kim, Y.H.; Gannon, M.; Lazar, M.A. HNF6 and Rev-erbalpha integrate hepatic lipid metabolism by overlapping and distinct transcriptional mechanisms. Genes Dev. 2016, 30, 1636-1644. [CrossRef]

240. Yuan, X.W.; Wang, D.M.; Hu, Y.; Tang, Y.N.; Shi, W.W.; Guo, X.J.; Song, J.G. Hepatocyte nuclear factor 6 suppresses the migration and invasive growth of lung cancer cells through p53 and the inhibition of epithelial-mesenchymal transition. J. Biol. Chem. 2013, 288, 31206-31216. [CrossRef] 
241. Jacquemin, P.; Durviaux, S.M.; Jensen, J.; Godfraind, C.; Gradwohl, G.; Guillemot, F.; Madsen, O.D.; Carmeliet, P.; Dewerchin, M.; Collen, D.; et al. Transcription factor hepatocyte nuclear factor 6 regulates pancreatic endocrine cell differentiation and controls expression of the proendocrine gene ngn3. Mol. Cell. Biol. 2000, 20, 4445-4454. [CrossRef]

242. Wang, K.; Wang, M.; Gannon, M.; Holterman, A. Growth Hormone Mediates Its Protective Effect in Hepatic Apoptosis through Hnf6. PLoS ONE 2016, 11, e0167085. [CrossRef]

243. Lahuna, O.; Fernandez, L.; Karlsson, H.; Maiter, D.; Lemaigre, F.P.; Rousseau, G.G.; Gustafsson, J.; Mode, A. Expression of hepatocyte nuclear factor 6 in rat liver is sex-dependent and regulated by growth hormone. Proc. Natl. Acad. Sci. USA 1997, 94, 12309-12313. [CrossRef] [PubMed]

244. Varga, T.; Czimmerer, Z.; Nagy, L. PPARs are a unique set of fatty acid regulated transcription factors controlling both lipid metabolism and inflammation. Biochim. Biophys. Acta 2011, 1812, 1007-1022. [CrossRef] [PubMed]

245. Pawlak, M.; Lefebvre, P.; Staels, B. Molecular mechanism of PPARalpha action and its impact on lipid metabolism, inflammation and fibrosis in non-alcoholic fatty liver disease. J. Hepatol. 2015, 62, 720-733. [CrossRef] [PubMed]

246. Patsouris, D.; Mandard, S.; Voshol, P.J.; Escher, P.; Tan, N.S.; Havekes, L.M.; Koenig, W.; Marz, W.; Tafuri, S.; Wahli, W.; et al. PPARalpha governs glycerol metabolism. J. Clin. Investig. 2004, 114, 94-103. [CrossRef] [PubMed]

247. Burri, L.; Thoresen, G.H.; Berge, R.K. The Role of PPARalpha Activation in Liver and Muscle. PPAR Res. 2010, 2010. [CrossRef] [PubMed]

248. Chandra, V.; Huang, P.; Hamuro, Y.; Raghuram, S.; Wang, Y.; Burris, T.P.; Rastinejad, F. Structure of the intact PPAR-gamma-RXR- nuclear receptor complex on DNA. Nature 2008, 456, 350-356. [CrossRef]

249. Dubuquoy, L.; Louvet, A.; Hollebecque, A.; Mathurin, P.; Dharancy, S. Peroxisome proliferator-activated receptors in HBV-related infection. PPAR Res. 2009, 2009, 145124. [CrossRef]

250. Raney, A.K.; Kline, E.F.; Tang, H.; McLachlan, A. Transcription and replication of a natural hepatitis B virus nucleocapsid promoter variant is regulated in vivo by peroxisome proliferators. Virology 2001, 289, 239-251. [CrossRef]

251. Shi, Y.; Li, Y.; Huang, C.; Ying, L.; Xue, J.; Wu, H.; Chen, Z.; Yang, Z. Resveratrol enhances HBV replication through activating Sirt1-PGC-1alpha-PPARalpha pathway. Sci. Rep. 2016, 6, 24744. [CrossRef]

252. Hu, W.; Wang, X.; Ding, X.; Li, Y.; Zhang, X.; Xie, P.; Yang, J.; Wang, S. MicroRNA-141 represses HBV replication by targeting PPARA. PLoS ONE 2012, 7, e34165. [CrossRef]

253. Zhang, X.K.; Hoffmann, B.; Tran, P.B.; Graupner, G.; Pfahl, M. Retinoid X receptor is an auxiliary protein for thyroid hormone and retinoic acid receptors. Nature 1992, 355, 441-446. [CrossRef] [PubMed]

254. Lee, M.S.; Kliewer, S.A.; Provencal, J.; Wright, P.E.; Evans, R.M. Structure of the retinoid X receptor alpha DNA binding domain: A helix required for homodimeric DNA binding. Science 1993, 260, 1117-1121. [CrossRef] [PubMed]

255. Song, M.; Sun, Y.; Tian, J.; He, W.; Xu, G.; Jing, Z.; Li, W. Silencing Retinoid X Receptor Alpha Expression Enhances Early-Stage Hepatitis B Virus Infection In Cell Cultures. J. Virol. 2018, 92. [CrossRef] [PubMed]

256. Wang, Y.D.; Chen, W.D.; Moore, D.D.; Huang, W. FXR: A metabolic regulator and cell protector. Cell Res. 2008, 18, 1087-1095. [CrossRef]

257. Pineda Torra, I.; Claudel, T.; Duval, C.; Kosykh, V.; Fruchart, J.C.; Staels, B. Bile acids induce the expression of the human peroxisome proliferator-activated receptor alpha gene via activation of the farnesoid $\mathrm{X}$ receptor. Mol. Endocrinol. 2003, 17, 259-272. [CrossRef]

258. Jiao, Y.; Lu, Y.; Li, X.Y. Farnesoid X receptor: A master regulator of hepatic triglyceride and glucose homeostasis. Acta Pharmacol. Sin. 2015, 36, 44-50. [CrossRef]

259. Claudel, T.; Staels, B.; Kuipers, F. The Farnesoid X receptor: A molecular link between bile acid and lipid and glucose metabolism. Arterioscler. Thromb. Vasc. Biol. 2005, 25, 2020-2030. [CrossRef]

260. Zhang, L.; Wang, Y.D.; Chen, W.D.; Wang, X.; Lou, G.; Liu, N.; Lin, M.; Forman, B.M.; Huang, W. Promotion of liver regeneration/repair by farnesoid $X$ receptor in both liver and intestine in mice. Hepatology 2012, 56, 2336-2343. [CrossRef]

261. Mangelsdorf, D.J.; Evans, R.M. The RXR heterodimers and orphan receptors. Cell 1995, 83, 841-850. [CrossRef] 
262. Thomas, A.M.; Hart, S.N.; Kong, B.; Fang, J.; Zhong, X.B.; Guo, G.L. Genome-wide tissue-specific farnesoid X receptor binding in mouse liver and intestine. Hepatology 2010, 51, 1410-1419. [CrossRef]

263. Curtil, C.; Enache, L.S.; Radreau, P.; Dron, A.G.; Scholtes, C.; Deloire, A.; Roche, D.; Lotteau, V.; Andre, P.; Ramiere, C. The metabolic sensors FXRalpha, PGC-1alpha, and SIRT1 cooperatively regulate hepatitis B virus transcription. FASEB J. 2014, 28, 1454-1463. [CrossRef] [PubMed]

264. Zhang, X.; Zhang, E.; Ma, Z.; Pei, R.; Jiang, M.; Schlaak, J.F.; Roggendorf, M.; Lu, M. Modulation of hepatitis B virus replication and hepatocyte differentiation by MicroRNA-1. Hepatology 2011, 53, 1476-1485. [CrossRef] [PubMed]

265. Kawata, H.; Yamada, K.; Shou, Z.; Mizutani, T.; Yazawa, T.; Yoshino, M.; Sekiguchi, T.; Kajitani, T.; Miyamoto, K. Zinc-fingers and homeoboxes (ZHX) 2, a novel member of the ZHX family, functions as a transcriptional repressor. Biochem. J. 2003, 373, 747-757. [CrossRef] [PubMed]

266. Liu, Y.; Ma, D.; Ji, C. Zinc fingers and homeoboxes family in human diseases. Cancer Gene Ther. 2015, 22, 223-226. [CrossRef]

267. Shen, H.; Luan, F.; Liu, H.; Gao, L.; Liang, X.; Zhang, L.; Sun, W.; Ma, C. ZHX2 is a repressor of alpha-fetoprotein expression in human hepatoma cell lines. J. Cell Mol. Med. 2008, 12, 2772-2780. [CrossRef]

268. Jiang, J.; Creasy, K.T.; Purnell, J.; Peterson, M.L.; Spear, B.T. Zhx2 (zinc fingers and homeoboxes 2) regulates major urinary protein gene expression in the mouse liver. J. Biol. Chem. 2017, 292, 6765-6774. [CrossRef]

269. Wan, F.; Gao, L.; Lu, Y.; Ma, H.; Wang, H.; Liang, X.; Wang, Y.; Ma, C. Proliferation and osteo/odontogenic differentiation of stem cells from apical papilla regulated by Zinc fingers and homeoboxes 2: An in vitro study. Biochem. Biophys. Res. Commun. 2016, 469, 599-605. [CrossRef]

270. Kwon, R.J.; Kim, Y.H.; Jeong, D.C.; Han, M.E.; Kim, J.Y.; Liu, L.; Jung, J.S.; Oh, S.O. Expression and prognostic significance of zinc fingers and homeoboxes family members in renal cell carcinoma. PLOS ONE 2017, 12, e0171036. [CrossRef]

271. Kawata, H.; Yamada, K.; Shou, Z.; Mizutani, T.; Miyamoto, K. The mouse zinc-fingers and homeoboxes (ZHX) family; ZHX2 forms a heterodimer with ZHX3. Gene 2003, 323, 133-140. [CrossRef]

272. Zhou, S.J.; Deng, Y.L.; Liang, H.F.; Jaoude, J.C.; Liu, F.Y. Hepatitis B virus X protein promotes CREB-mediated activation of miR-3188 and Notch signaling in hepatocellular carcinoma. Cell Death Differ. 2017, 24, 1577-1587. [CrossRef]

273. Song, X.; Tan, S.; Wu, Z.; Xu, L.; Wang, Z.; Xu, Y.; Wang, T.; Gao, C.; Gong, Y.; Liang, X.; et al. HBV suppresses ZHX2 expression to promote proliferation of HCC through miR-155 activation. Int. J. Cancer 2018, 143, 3120-3130. [CrossRef] [PubMed]

274. Gray, S.; Wang, B.; Orihuela, Y.; Hong, E.G.; Fisch, S.; Haldar, S.; Cline, G.W.; Kim, J.K.; Peroni, O.D.; Kahn, B.B.; et al. Regulation of gluconeogenesis by Kruppel-like factor 15. Cell Metab. 2007, 5, 305-312. [CrossRef] [PubMed]

275. Takashima, M.; Ogawa, W.; Hayashi, K.; Inoue, H.; Kinoshita, S.; Okamoto, Y.; Sakaue, H.; Wataoka, Y.; Emi, A.; Senga, Y.; et al. Role of KLF15 in regulation of hepatic gluconeogenesis and metformin action. Diabetes 2010, 59, 1608-1615. [CrossRef] [PubMed]

276. Matoba, K.; Lu, Y.; Zhang, R.; Chen, E.R.; Sangwung, P.; Wang, B.; Prosdocimo, D.A.; Jain, M.K. Adipose KLF15 Controls Lipid Handling to Adapt to Nutrient Availability. Cell Rep. 2017, 21, 3129-3140. [CrossRef]

277. Pei, J.; Grishin, N.V. C2H2 zinc finger proteins of the SP/KLF, Wilms tumor, EGR, Huckebein, and Klumpfuss families in metazoans and beyond. Gene 2015, 573, 91-99. [CrossRef]

278. Fernandez-Marcos, P.J.; Auwerx, J.; Schoonjans, K. Emerging actions of the nuclear receptor LRH-1 in the gut. Biochim. Biophys. Acta 2011, 1812, 947-955. [CrossRef]

279. Fayard, E.; Auwerx, J.; Schoonjans, K. LRH-1: An orphan nuclear receptor involved in development, metabolism and steroidogenesis. Trends Cell Biol. 2004, 14, 250-260. [CrossRef]

280. Yumoto, F.; Nguyen, P.; Sablin, E.P.; Baxter, J.D.; Webb, P.; Fletterick, R.J. Structural basis of coactivation of liver receptor homolog-1 by beta-catenin. Proc. Natl. Acad. Sci. USA 2012, 109, 143-148. [CrossRef]

281. Holmstrom, S.R.; Deering, T.; Swift, G.H.; Poelwijk, F.J.; Mangelsdorf, D.J.; Kliewer, S.A.; MacDonald, R.J. LRH-1 and PTF1-L coregulate an exocrine pancreas-specific transcriptional network for digestive function. Genes Dev. 2011, 25, 1674-1679. [CrossRef]

282. Stein, S.; Oosterveer, M.H.; Mataki, C.; Xu, P.; Lemos, V.; Havinga, R.; Dittner, C.; Ryu, D.; Menzies, K.J.; Wang, X.; et al. SUMOylation-dependent LRH-1/PROX1 interaction promotes atherosclerosis by decreasing hepatic reverse cholesterol transport. Cell Metab. 2014, 20, 603-613. [CrossRef] 
283. Pollicino, T.; Belloni, L.; Raffa, G.; Pediconi, N.; Squadrito, G.; Raimondo, G.; Levrero, M. Hepatitis B virus replication is regulated by the acetylation status of hepatitis B virus cccDNA-bound $\mathrm{H} 3$ and $\mathrm{H} 4$ histones. Gastroenterology 2006, 130, 823-837. [CrossRef] [PubMed]

284. Tu, T.; Budzinska, M.A.; Shackel, N.A.; Urban, S. HBV DNA Integration: Molecular Mechanisms and Clinical Implications. Viruses 2017, 9, 75. [CrossRef] [PubMed]

285. Moyo, B.; Bloom, K.; Scott, T.; Ely, A.; Arbuthnot, P. Advances with using CRISPR/Cas-mediated gene editing to treat infections with hepatitis B virus and hepatitis C virus. Virus Res. 2018, 244, 311-320. [CrossRef] [PubMed]

286. Schiwon, M.; Ehrke-Schulz, E.; Oswald, A.; Bergmann, T.; Michler, T.; Protzer, U.; Ehrhardt, A. One-Vector System for Multiplexed CRISPR/Cas9 against Hepatitis B Virus cccDNA Utilizing High-Capacity Adenoviral Vectors. Mol. Ther Nucleic Acids 2018, 12, 242-253. [CrossRef] [PubMed]

287. Chen, Y.; Cheng, G.; Mahato, R.I. RNAi for treating hepatitis B viral infection. Pharm. Res. 2008, 25, 72-86. [CrossRef] [PubMed]

288. Flisiak, R.; Jaroszewicz, J.; Lucejko, M. siRNA drug development against hepatitis B virus infection. Expert Opin. Biol. Ther. 2018, 18, 609-617. [CrossRef] [PubMed]

289. Huang, Y. Preclinical and Clinical Advances of GalNAc-Decorated Nucleic Acid Therapeutics. Mol. Ther Nucleic Acids 2017, 6, 116-132. [CrossRef]

290. Hong, X.; Kim, E.S.; Guo, H. Epigenetic regulation of hepatitis B virus covalently closed circular DNA: Implications for epigenetic therapy against chronic hepatitis B. Hepatology 2017, 66, 2066-2077. [CrossRef]

291. Nehme, Z.; Pasquereau, S.; Herbein, G. Control of viral infections by epigenetic-targeted therapy. Clin. Epigenetics 2019, 11, 55. [CrossRef]

292. Tropberger, P.; Mercier, A.; Robinson, M.; Zhong, W.; Ganem, D.E.; Holdorf, M. Mapping of histone modifications in episomal HBV cccDNA uncovers an unusual chromatin organization amenable to epigenetic manipulation. Proc. Natl. Acad. Sci. USA 2015, 112, E5715-E5724. [CrossRef]

293. Guo, J.T.; Guo, H. Metabolism and function of hepatitis B virus cccDNA: Implications for the development of cccDNA-targeting antiviral therapeutics. Antivir. Res. 2015, 122, 91-100. [CrossRef] [PubMed]

294. Bonvin, A.M.; Boelens, R.; Kaptein, R. NMR analysis of protein interactions. Curr. Opin. Chem. Biol. 2005, 9, 501-508. [CrossRef] [PubMed]

295. Shi, Y. A glimpse of structural biology through X-ray crystallography. Cell 2014, 159, 995-1014. [CrossRef]

296. Venien-Bryan, C.; Li, Z.; Vuillard, L.; Boutin, J.A. Cryo-electron microscopy and X-ray crystallography: Complementary approaches to structural biology and drug discovery. Acta Crystallogr. F Struct. Biol. Commun. 2017, 73, 174-183. [CrossRef] [PubMed]

297. Patel, T.R.; Chojnowski, G.; Koul, A.; McKenna, S.A.; Bujnicki, J.M. Structural studies of RNA-protein complexes: A hybrid approach involving hydrodynamics, scattering, and computational methods. Methods 2017, 118-119, 146-162. [CrossRef] [PubMed]

(C) 2020 by the authors. Licensee MDPI, Basel, Switzerland. This article is an open access article distributed under the terms and conditions of the Creative Commons Attribution (CC BY) license (http://creativecommons.org/licenses/by/4.0/). 